\title{
Mineral Chemistry, S-Pb-O Isotopes, and S/Se Ratios of the Niubiziliang Ni-(Cu) Sulfide Deposit in North Qaidam Orogenic Belt, NW China: Constraints on the Parental Magma Composition, Evolution, and Sulfur Saturation Mechanism
}

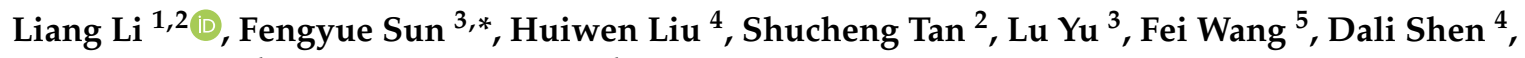 \\ Xueping Wang ${ }^{4}$ and Yonggang Wang ${ }^{4}$ \\ 1 Yunnan Key Laboratory of Statistical Modeling and Data Analysis, Department of Statistics, \\ Yunnan University, Kunming 650500, China; liliang19@ynu.edu.cn \\ 2 School of Earth Sciences, Yunnan University, Kunming 650500, China; shchtan@ynu.edu.cn \\ 3 College of Earth Sciences, Jilin University, Changchun 130061, China; yulujlu@hotmail.com \\ 4 The Nuclear Industry Bureau of Qinghai Province, Xining 810008, China; liuhuiwen2008@21cn.com (H.L.); \\ dlshennibq@126.com (D.S.); xpwangnibq@126.com (X.W.); ygwangnibq@126.com (Y.W.) \\ 5 School of Computer and Information Engineering, Heilongjiang University of Science and Technology, \\ Harbin 150022, China; fwanghust@126.com \\ * Correspondence: sfy@jlu.edu.cn
}

Received: 3 July 2020; Accepted: 16 September 2020; Published: 23 September 2020

\begin{abstract}
The Niubiziliang Ni-(Cu) deposit is the first magmatic Ni-Cu sulfide deposit in the North Qaidam Orogenic Belt (NQOB), NW China, and plays a significant role in geological evolution, $\mathrm{Ni}-\mathrm{Cu}$ mineralization, and exploration in the NQOB. Here, we report on the mineral chemistry, $\mathrm{S}-\mathrm{Pb}-\mathrm{O}$ isotopes, and $\mathrm{S} / \mathrm{Se}$ ratios of the mafic-ultramafic complex, which provide insights on the parental magma, evolution, and sulfur saturation mechanism. The Niubiziliang mafic-ultramafic intrusion contains four ore blocks and about ten $\mathrm{Ni}-(\mathrm{Cu})$ ore/mineralization bodies. Olivines in Niubiziliang belong to the species of chrysolite with Fo values of $88 \sim 89$, and the pyroxenes are mainly orthopyroxene $(E n=79 \sim 82)$ and clinopyroxene $(E n=44 \sim 40)$. The olivines and some pyroxenes likely crystallized in a magma chamber at a depth of $35.45 \sim 36.55 \mathrm{~km}$ at a high temperature $\left(1289 \sim 1369^{\circ} \mathrm{C}\right)$ and pressure (9.38 9.67 kbar), whereas the Niubiziliang complex formed at a moderate depth $(8.13 \sim 8.70 \mathrm{~km})$ with a temperature and pressure of $1159 \sim 1253^{\circ} \mathrm{C}$ and $2.15 \sim 2.30 \mathrm{kbar}$, respectively. The parental magma was considered to be high-Mg picritic basalt with $\mathrm{MgO}$ and $\mathrm{NiO}$ contents of $14.95 \sim 16.58 \%$ and $0.053 \sim 0.068 \%$, respectively, which indicated high-degree partial melting of the depleted mantle. The mantle-derived primary magma underwent significant fractional crystallization and crustal assimilation and contamination, which was strongly supported by S-Pb-O isotope data and $\mathrm{S} / \mathrm{Se}$ ratios, resulting in sulfur saturation and sulfide immiscibility in the magma. Crustal assimilation and contamination contributed more to sulfur saturation than fractional crystallization.
\end{abstract}

Keywords: mineral chemistry; $\mathrm{S} / \mathrm{Se}$ ratios; crustal contamination; Niubiziliang $\mathrm{Ni}-(\mathrm{Cu})$ sulfide deposit; NW China

\section{Introduction}

The magmatic Cu-Ni-PGE sulfide deposits associated with the mafic-ultramafic complex host major $\mathrm{Ni}, \mathrm{Cu}, \mathrm{Co}$, and PGE resources, and have significant implications for the evolution of the mantle, magmatism, tectonics, and geodynamic evolution [1]. They are generally characterized by large-scale, 
high-grade Ni-Cu-PGE; tractability; and a concentrated distribution. Several world-class Cu-Ni-(PGE) deposits, including Sudbury, Noirl'sk, Bushveld, Jinchuan, Voisey's Bay, Duluth, Thompson, Mt. Keith, Perchenga, and Yilgam deposits, host the majority of global Ni and PGE resources [2-5]. Consequently, metallogenic dynamics, genesis, metallogenic mechanisms, and explorations for magmatic Ni-Cu-PGE deposits, especially world-class deposits, have attracted a large number of researchers [2-10]. The parental magma composition, magmatic evolution, and sulfur saturation mechanism have been longstanding concerns for researchers. Naldrett (1995) proposed three key factors for the genesis of world-class Cu-Ni-PGE deposits [3]: (a) The host magma must become saturated in sulfide and segregated immiscible sulfide; (b) these sulfides must react with a sufficient amount of magma to concentrate chalcophile elements to an economic level; and (c) the sulfides must themselves be concentrated in a restricted locality to constitute an ore body. The author also suggested that the segregation of liquid sulfide, coupled with settling of the sulfide to form rich basal accumulations, was not part of the normal cooling and crystallization of mafic-ultramafic magma; that is to say, the fractional crystallization of magma had little effect on the sulfur saturation. Conversely, the mixing of mafic-ultramafic magma with a felsic contaminant could lower the ability of the resulting hybrid to dissolve sulfides, resulting in immiscibility, which plays a major role in sulfide segregation [10].

Niubiziliang is the first known magmatic $\mathrm{Cu}-\mathrm{Ni}$ sulfide deposit with economic significance in the North Qaidam Orogenic Belt (NQOB). It is located in the Altun region of the northwestern margin of Qaidam Basin and its geotectonic location is the westernmost segment of the NQOB. The Niubiziliang $\mathrm{Ni}-(\mathrm{Cu})$ deposit was discovered by the Qinghai Geological Bureau of Nuclear Industry in 2008, during an investigation of the $\mathrm{Cu}-\mathrm{Co}-\mathrm{Ni}-\mathrm{Cr}$ drainage anomaly. Several ore-bearing ultramafic intrusions and $12 \mathrm{Ni}-(\mathrm{Cu})$ ore/mineralization bodies were found in 2009 2010 [11,12], in which a massive $\mathrm{Cu}-\mathrm{Ni}$ ore was found at depth in the No. II ore block, with an average grade of $0.56 \%$ and a maximum of $1.57 \%$ $\mathrm{Ni}$, which drove further explorations for $\mathrm{Cu}-\mathrm{Ni}$ sulfide deposits at the time. The discovery of the Niubiziliang Ni-(Cu) deposit broadened the potential for further exploration, and is also significant in terms of the tectonic, magmatic, and dynamic evolution of the northern margin of Qaidam.

Previous studies on the Niubiziliang Ni-(Cu) deposit have mainly focused on the deposit geology, metallogenic age, deposit genesis, metallotectonic background, nature of the magmatic source area, and magmatic evolution [11-16]. Yu et al. (2019) proposed that the Niubiziliang mafic-ultramafic complex was formed during post-orogenic extension in the middle-late Devonian and that the primary magma originated from the partial melting of the asthenosphere mantle that was previously metasomatized by subduction-related fluids [16]. Ling et al. (2014a and 2014b) considered that the primary magma of the Niubiziliang mafic-ultramafic complex was a tholitic basaltic magma with an $\mathrm{MgO}$ content of $10.8 \%$, and that a low degree of partial melting in the mantle source led to the loss of PGE from the magma $[13,14]$. Presently, researchers generally agree that Niubiziliang is a magmatic $\mathrm{Cu}-\mathrm{Ni}$ sulfide deposit, which formed in a Devonian extensional environment at the northern margin of Qaidam Massif and that fractional crystallization and crustal contamination took place extensively in the ore-forming process. However, the mineralogy and isotope geochemistry of the Niubiziliang mafic-ultramafic complex are relatively poorly understood, so the primary magma composition, magmatic evolution, sulfide saturation mechanism, and their constraints on mineralization also remain poorly understood. One controversy is that although Ling et al. (2014a) [13] estimated the $w_{\mathrm{MgO}}$ of the primary magma in the Niubiziliang complex to be $10.8 \%$, the Fo value of olivine used in the calculation was too low. Our paper attempts to determine the parental magma composition, crystallization conditions, magmatic evolution, sulfur saturation mechanism, and their constraints on mineralization through a systematic study of the mineralogy, O-S-Pb isotope geochemistry, and $\mathrm{S} / \mathrm{Se}$ ratios in this complex, in order to provide new insights into the metallogenesis of the Niubiziliang $\mathrm{Ni}-(\mathrm{Cu})$ sulfide deposit. 


\section{Regional Geology}

The Niubiziliang Ni-(Cu) deposit is located in the northwestern margin of Qaidam Massif and the southern slope of the Altun Mountains, and is also the intersection of the Altun Orogenic Belt (AOB) and the NQOB (Figure 1a). The metallogenic belt in which the Niubiziliang Ni-(Cu) deposit is located belongs to the metallogenic belt of Hercynian iron, copper, lead, zinc, rare earth elements, tungsten, and bismuth. The northwestern margin of the Qaidam Basin is located in an area where multiple geological structures are complex, intersecting, and undergoing multiple tectonic overlaying and transformation. This area has experienced multiple tectonic and magmatic activities, from Archean to Cenozoic, and a large number of geological records provide good information for researching this area. The strata in this area are simple, the tectonic framework is clear, and the magmatism of different ages is very intense, especially the strong extensional background, which provide important tectonic preconditions for mafic-ultramafic magmatism and mineralization. However, the activity of the Altun Tagh fault began in the late Triassic [17], which has had a strong controlling effect on the uplift of the northern boundary of the Qinghai-Tibet Plateau. This occurred later than the formation of the Niubiziliang $\mathrm{Ni}-(\mathrm{Cu})$ deposit and belonged to a post-metallogenic fault, which had a destructive effect on this deposit. Therefore, the formation of the Hercynian mafic-ultramafic rocks and $\mathrm{Cu}-\mathrm{Ni}$ deposits in the northwestern margin of Qaindam Massif was not related to the formation and evolution of the AOB, but was related to the NQOB (Figure 1b).

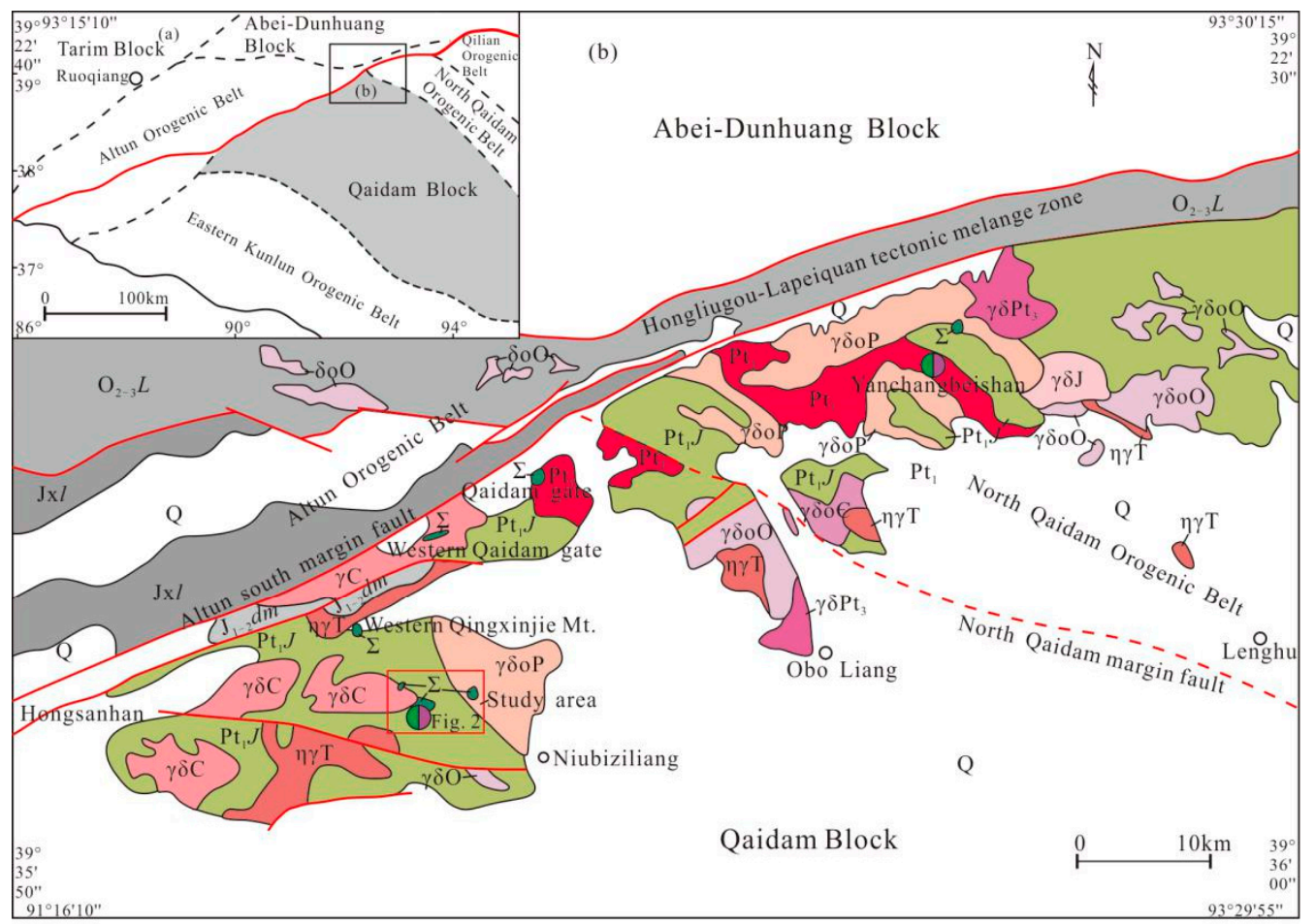

\begin{tabular}{|c|c|c|c|c|c|c|c|c|c|}
\hline Q & $\begin{array}{l}\text { Quaternary } \\
\text { sediments }\end{array}$ & $\mathrm{J}_{1-2} d m$ & $\begin{array}{l}\text { Early-Middle Jurassic } \\
\text { Dameigou Formation }\end{array}$ & $\mathrm{O}_{2-3} \mathrm{~L}$ & $\begin{array}{l}\text { Early-Middle Ordovician } \\
\text { Lapeiquan Formation }\end{array}$ & $\mathrm{Jx} l$ & $\begin{array}{l}\text { Jixian Period Lang- } \\
\text { yashan Formation }\end{array}$ & $\mathrm{Pt}_{1} J$ & $\begin{array}{l}\text { Paleoproterozoic } \\
\text { Jinshuikou Group }\end{array}$ \\
\hline J & $\mid \begin{array}{l}\text { Jurassic } \\
\text { intrusive rock }\end{array}$ & $\mathrm{T}$ & $\begin{array}{l}\text { Triassic } \\
\text { intrusive rock }\end{array}$ & P & $\begin{array}{l}\text { Permian intrusive } \\
\text { rock }\end{array}$ & C & $\begin{array}{l}\text { Carboniferous } \\
\text { intrusive rock }\end{array}$ & D & $\begin{array}{l}\text { Devonian intrusive } \\
\text { rock }\end{array}$ \\
\hline $\mathrm{O}$ & $\begin{array}{l}\text { Ordovician } \\
\text { intrusive rock }\end{array}$ & $\epsilon$ & $\begin{array}{l}\text { Cambrian } \\
\text { intrusive rock }\end{array}$ & $\mathrm{Pt}_{\text {t }}$ & $\begin{array}{l}\text { Neoproterozoic } \\
\text { intrusive rock }\end{array}$ & P & $\begin{array}{l}\text { Paleoproterozoic } \\
\text { intrusive rock }\end{array}$ & $\gamma$ & Granite \\
\hline$\gamma \delta$ & Granodiorite & $\gamma \delta \mathrm{o}$ & Tonalite & $\delta$ & Diorite & so & Quartz diorite & $\eta \gamma$ & Monzonitic granite \\
\hline$\Sigma$ & $\begin{array}{l}\text { Mafic-ultramafic } \\
\text { rock }\end{array}$ & & Fault & & Concealed fault & (1) & $\mid \begin{array}{l}\mathrm{Cu}-\mathrm{Ni} \text { sulfide } \\
\text { deposit }\end{array}$ & & Study area \\
\hline
\end{tabular}

Figure 1. Structural location map (a) and geological sketch map (b) of the northern margin of Qaidam Basin (modified after Qian et al. (2015) [15]).

The strata in the study area mainly include Paleoproterozoic Jinshuikou Group, Jurassic Dameigou Formation, Neogene Youshashan Formation, and Quaternary sediment strata. The Jinshuikou Group 
is the main stratum in the study area, which can be divided into gneiss formation and marble formation. The Jinshuiou Group in the Niubiziiliang Ni- $(\mathrm{Cu})$ mining area is mainly gneiss formation with NW-SE strike, and the lithology is dominated by Biotite plagiogneiss with some sericite-quartz schist, muscovite-bearing quartzite, and tremolite-bearing marble. The Altun south margin fault, north Qaidam margin fault, and Hongsanhan-Niubiziliang fault formed the regional structural framework of the northwestern margin of Qaidam Massif. At the same time, many ductile shear zones, folds, and joints were formed, which had an important influence on the tectonism and magmatism in this area. The faults can be divided into four groups according to the strike, including a nearly SE direction, NE-SW direction, NW-SE direction, and NS direction. The NE-SW faults are related to the formation of the AOB, while the NW-SE faults are likely related to the formation and evolution of the NQOB. The magmatic rocks in this area are widely distributed, large in scale, and mainly intrusive rocks, with poor volcanic rocks. The intrusive rocks were developed from ultrabasic to acidic with many types of rocks and were mainly formed in the Luliang, Jinning, Hercynian, and Indosinian periods, among which Hercynian and Indosinian acid intrusive rocks represent the most developed. Basic-ultrabasic rocks, including Niubiziliang, Yanchangbeishan, Qaidam gate, western Qaidam gate, and western Qingxinjie Mt. rocks, have mainly been produced as complex or vein-like forms, and are distributed sporadically (Figure 1b). The Cu-Ni mineralization in the study area is almost entirely related to the mafic-ultramafic complex. The most Hercynian diorites, granites, and other intrusive rocks intruded at the strong extensional background after the closure of the northern margin of the Qaidam Massif Ocean (NMQMO), which is consistent with that of the mafic-ultramafic rocks in Niubiziliang [18,19].

\section{Deposit Geology}

\subsection{Mining Area Geology}

The strata in the Niubiziliang $\mathrm{Ni}-(\mathrm{Cu})$ mining area are dominated by the Paleoproterozoic Jinshuikou Group and Quaternary sedimentary successions (Figure 2). The Jinshuiokou Group is a set of gneiss with intense migmatitization, mainly including biotite plagiogneiss, amphibolite gneiss, and tremolite marble [11]. The Quaternary sediments are mainly composed of sand, gravel, and sand oil.

The faults in the Niubiziliang mining area were all formed during the post-mineralization stage and some of them had a destructive effect on the deposit. According to the orientation, they can be divided into two groups, as follows: The NE-SW and NW-SE trending fault systems. Among these, the $\mathrm{F}_{1}$ fault has the largest scale and almost runs through the whole mining area. This fault strikes the $\mathrm{NE}$ and dips to the NW, whereas the middle of $\mathrm{F}_{1}$ dips to the SE. This gives the interpretation that the $F_{1}$ is a sinistral translational fault with normal fault characteristics [20]. It divides the original ore-hosted ultramafic intrusion into the No. II and III ore blocks (Figure 2). The eastern part of $F_{1}$ is covered by the Quaternary sediments, forming a large gully. The normal fault effect of $F_{1}$ relatively lowers the No. II ore block in the hanging wall and raises the No. III ore block in the footwall. Due to this, under the same denudation conditions after mineralization, the ore-hosted ultramafic intrusion in the No. III ore block was exposed on the surface and the bottom ore body in the No. II ore block was preserved.

The Niubiziliang mafic-ultramafic complex, which formed in the Devonian period (367 Ma [13], 388 402 Ma [15], and 373 389 Ma [16]), is the metallogenic intrusion of the Niubiziliang Ni-(Cu) sulfide deposit. The rocks from the peridotite facies to the gabbro facies are well-developed in this mafic-ultramafic complex, and the harzburgite is the most important ore-hosting rock. Devonian magmatic rocks, mainly including diorite and granite, are the products of magmatic activities after mineralization and have a great influence on the preservation of the deposit $[19,21]$. Dark inclusions are common in the diorite, the condensation edge of which develops crystalline rings. The monzonitic 
granite is widely exposed in the central and northeastern part of the mining area and intruded into the mafic-ultramafic complex, having a very destructive effect on the No. I ore block.

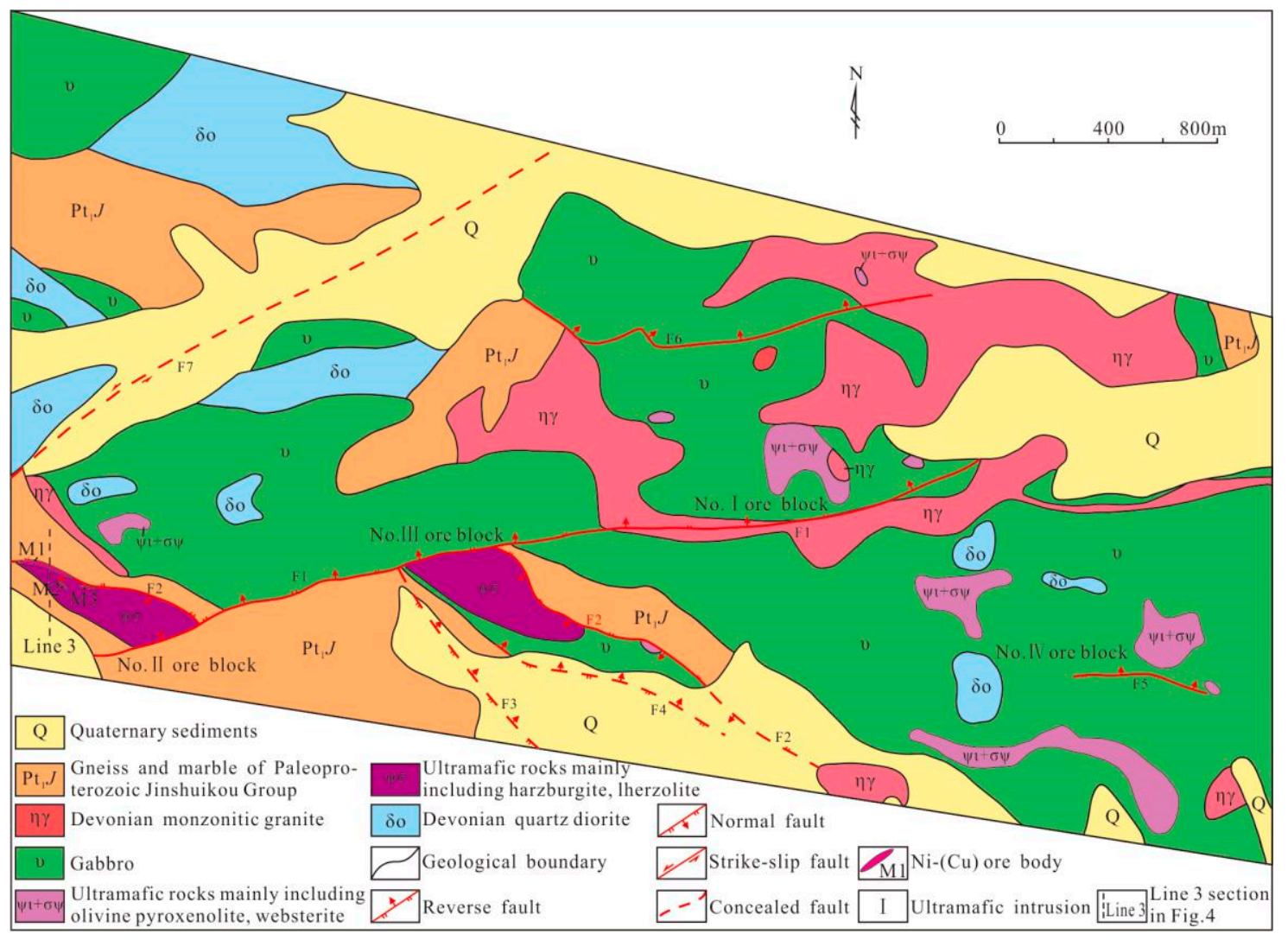

Figure 2. Geological map of the Niubiziliang Ni-(Cu) deposit (modified after Zhao et al. (2012a) [11]).

\subsection{Mafic-Ultramafic Intrusions}

The Niubiziliang Ni-(Cu) deposit can be divided into four ore blocks according to the location of ultramafic intrusion (Figures 2 and 3), among which the Ni-(Cu) ore bodies are mainly hosted in the No. II and III ultramafic intrusions [20]. Gabbros in this deposit are widely distributed, forming the main part of the complex, and the ultramafic intrusions output in stocks into the gabbro or Jinshuikou Group gneiss. The exposed areas of ultramafic intrusions in the four ore blocks are different and the overall areas are small, mostly ranging between 0.08 and $0.12 \mathrm{~km}^{2}$. There are a few banded cumulate gabbros in the No. I ore block and the No. IV ore block is composed of widely distributed gabbros and three small separated outcrops of ultramafic rocks. The ore-hosting ultramafic intrusions in No. II and III ore blocks originally belonged to the same intrusion, which was divided into two isolated intrusions by the $F_{1}$ fault. The ultramafic rocks in No. I and IV ore blocks are mainly pyroxenite, websterite, and olivine pyroxenite, whereas the ultramafic rocks in the No. II and III ore blocks are dominated by harzburgite and lherzolite (Figure 3). 

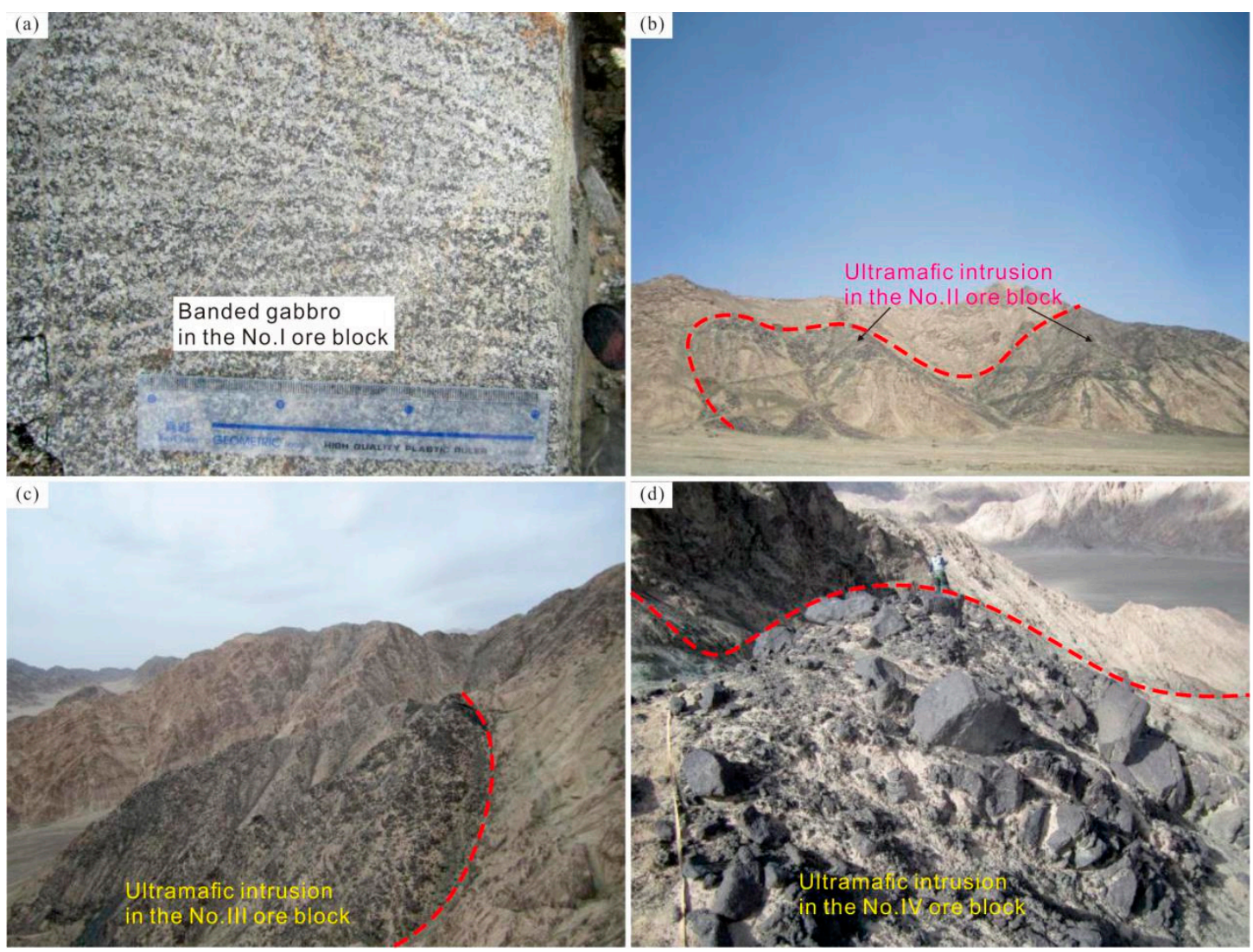

Figure 3. Representative field photographs of the Niubiziliang mafic-ultramafic complex. (a) Banded gabbro from the No. I ore block; (b) Ore-bearing ultramafic intrusion from the No. II ore block; (c) Ore-bearing ultramafic intrusion from the No. III ore block; (d) Ultramafic intrusion from the No. IV ore block.

The Niubiziliang ore-forming pluton is a complex which was formed by the multiple emplacement of mafic-ultramafic magmas in the Devonian period [16], and was then intruded by post-metallogenic diorite and granite as dyke or stock. It is inferred that there are two possible shapes of the deep ultramafic intrusion based on a large number of drill holes and magnetic data, as follows: (a) Intruding the gabbros as stock, such as the No. I and IV ore blocks. The ultramafic intrusion in the No. IV ore block is a semi-steep lopolith in space, and the ultramafic rocks on the surface are the outcrops of the lopolith edge. The second is (b) intruding the gabbros or gneiss as a steeply dipping and gentle-lateral-trending apophysis, such as the No. II and III ore blocks. They are controlled by the NW trending fault with striking NW and dipping SW (Figure 4). The shape of the ultramafic intrusion has a strong effect on the location of the ore body. The steeply dipping apophysis usually forms the hanging orebody, while the semi-steep lopolith tends to form the bottom ore body. 


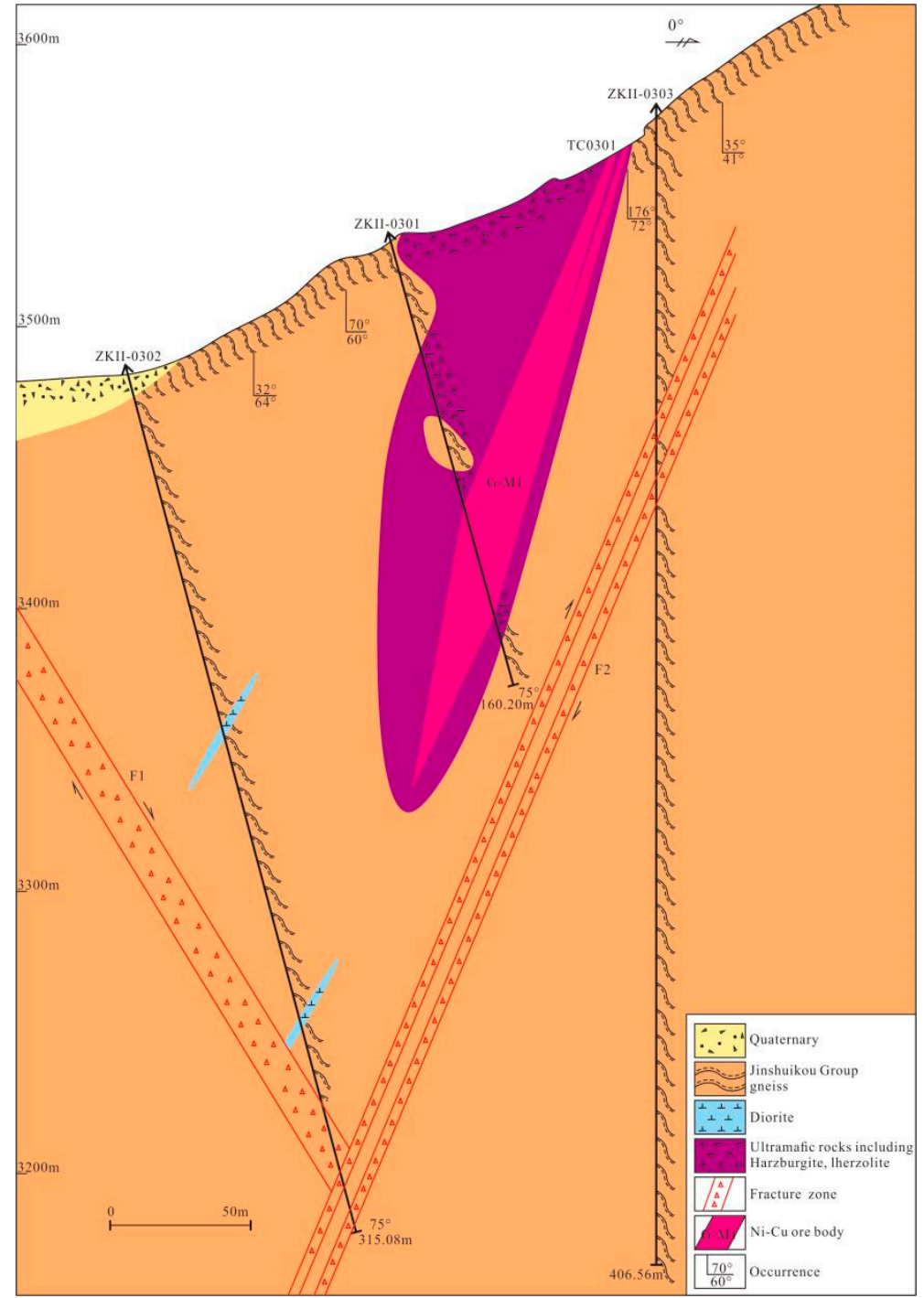

Figure 4. The line 3 section of the No. II ore block in the Niubiziliang Ni-(Cu) deposit (modified after Zhao et al. (2012a) [11]).

\subsection{Ni-(Cu) Ore Body and Mineralization}

\subsubsection{Characteristics of $\mathrm{Ni}-(\mathrm{Cu})$ Ore Body}

The mineralization in the four ore blocks is quite different. In general, the gabbro is rarely mineralized, with starspot pyrite occurring locally, whereas the ultramafic rocks mainly include starspot, disseminated, sideronitic, and crumby/massive sulfides. Most ultramafic intrusions contain starspot and disseminated sulfides, but their grades of $\mathrm{Cu}, \mathrm{Ni}$, and $\mathrm{Co}$ are generally low, with no economic value. The amount of sulfide is closely related to the content of olivine, for example, the harzburgite and lherzolite in the No. II and III ore blocks contain more sulfides than pyroxenite and websterite in the No. I and IV ore blocks. The ore body is usually formed by ultramafic rocks with sideronitic or crumby/massive sulfides, with a generally high grade of $\mathrm{Cu}, \mathrm{Ni}$, and $\mathrm{Co}$. About 10 ore bodies (including concealed ore bodies) are defined in the No. II and III ore blocks at present, and their characteristics are listed in Table 1. However, there are no ore bodies in the No. I and IV ore blocks, in which ultramafic rocks only contain starspot or disseminated sulfides.

Five ore/mineralization Ni-(Cu) bodies can be found in the No. II ore block, including one Ni-Cu industrial ore body (G-M1), two low-grade ore bodies (D-M1 and D-M2), and two mineralization bodies (M3 and M4). The M1 M3 ore bodies occur in the cracked harzburgite and lherzolite in the 
$\mathrm{F}_{3}$ fracture zone dipping to $\mathrm{S}$ at $72^{\circ}$, in which the hanging wall is ore-bearing harzburgite and the footwall is Jinshuikou Group gneiss (Figure 4). The other five ore/mineralization bodies have the same ore rock, sulfide assemblage, and texture. They are a group of ore bodies of the same type, and their ore rocks are all harzburgite and lherzolite. The G-M1 ore body contains massive ores, whereas the others mainly contain disseminated sulfides. Prryhotite, pentlandite, and chalcopyrite are the main sulfides of the ore bodies, and the more sulfides, the higher the ore grade.

Seven Ni-(Cu) ore/mineralization bodies have been found in the No. III ore block, all of which are concealed ore bodies, including two industrial ore bodies (M7 and G-M10), four low-grade ore bodies (M6, M8, M9, and D-M10), and one mineralization body (M5). The rock core of ZKIII-0801 and ZKIII-1601 in the G-M1 ore body contains many massive ores and has a high content of sulfides, with a maximum value of about $80 \%$.

\subsubsection{Sulfides and $\mathrm{Ni}-(\mathrm{Cu})$ Mineralization}

Pyrrhotite, pentlandite, chalcopyrite, and pyrite are the main sulfides of the Niubiziliang Ni-(Cu) deposit, with minor amounts of violarite, bornite, magnetite, and ilmenite (Figure 5), and there are a few supergene minerals (e.g., malachite, annabergite, and limonite) in the surface. They are often disseminated, while sideronitic and massive sulfides occur locally. Pentlandite usually occurs in the inner or outer margin of pyrrhotite in the form of xenomorphic aggregates, showing a typical exsolution texture and sulfide assemblage in the magmatic $\mathrm{Ni}-\mathrm{Cu}$ sulfide deposit.

Pyrite is the most widely distributed sulfide in Niubiziliang, with a variable content of $5 \sim 20 \%$. It generally has a xenomorphic-hypautomorphic granularity, is vein-like, and is crumby in shape, with a size of $0.05 \sim 2.50 \mathrm{~mm}$ (Figure 5a). The vein-like pyrites formed in the late stage often cut the early rocks and sulfides.

The pyrrhotite is distributed between the gangue minerals in the form of a xenomorphic or irregular granularity, with a size of $0.02 \sim 1.00 \mathrm{~mm}$. It generally coexists with pentlandite and chalcopyrite, and the contact boundary between them is smooth and straight, showing a common symbiotic texture (Figure 5b-d). 
Table 1. Characteristics of the Ni-(Cu) ore/mineralization body in the Niubiziliang Ni-(Cu) deposit.

\begin{tabular}{|c|c|c|c|c|c|c|c|c|c|c|}
\hline \multirow{2}{*}{ Ore Block } & \multirow{2}{*}{\multicolumn{2}{|c|}{ Ore Body }} & \multirow{2}{*}{ Type of Ore Body } & \multirow{2}{*}{ Length $(\mathrm{m})$} & \multirow{2}{*}{ Thickness (m) } & \multirow{2}{*}{ Occurrence } & \multirow{2}{*}{$\begin{array}{l}\text { Mineralization } \\
\text { Characteristics }\end{array}$} & \multicolumn{3}{|c|}{ Ore Grade } \\
\hline & & & & & & & & $\mathrm{Ni}(\%)$ & $\mathrm{Cu}(\%)$ & $\mathrm{Co}(\%)$ \\
\hline \multirow[t]{5}{*}{ Ore block II } & \multirow[t]{2}{*}{ M1 } & G-M1 & $\begin{array}{l}\text { High-grade } \\
\text { industrial ore body }\end{array}$ & 200 & $1.22 \sim 22.6$ & $174^{\circ} \angle 72^{\circ}$ & $\begin{array}{l}\text { It contains massive ores, which } \\
\text { mainly includes pyrrhotite, } \\
\text { chalcopyrite, and pentlandite } \\
\text { with many hydrothermal } \\
\text { pyrites as well, and the hosted } \\
\text { rocks are mainly harzburgite } \\
\text { and lherzaolite. }\end{array}$ & Max 1.57 , average 0.50 & $\begin{array}{c}\text { Max 0.79, } \\
\text { average 0.29 }\end{array}$ & $\begin{array}{c}\text { Max } 0.079 \\
\text { average } 0.030\end{array}$ \\
\hline & & D-M1 & Low-grade ore body & 100 & 1.18 & & \multirow{11}{*}{$\begin{array}{l}\text { The ore-hosted rocks are } \\
\text { mainly harzburgite, lherzolite } \\
\text { and olivine pyroxenite with the } \\
\text { major disseminated sulfides } \\
\text { and locally crumb, sideronitic } \\
\text { sulfides. They contain variable } \\
\text { amounts pyrrhotites, } \\
\text { chalcopyrites, pentlandites and } \\
\text { pyrites, and the higher contents } \\
\text { of sulfide, the higher ore grade. }\end{array}$} & $0.21 \sim 0.36$, average 0.24 & $0.19 \sim 0.26$ & $0.015 \sim 0.029$ \\
\hline & & & Low-grade ore body & 80 & 1.50 & $194^{\circ} \angle 67^{\circ}$ & & $0.20 \sim 0.30$, average 0.23 & $0.11 \sim 0.12$ & $0.023 \sim 0.025$ \\
\hline & & & Mineralization body & & 0.92 & & & Average 0.21 & Average 0.12 & Average 0.016 \\
\hline & & & $\begin{array}{c}\text { Concealed } \\
\text { mineralization body }\end{array}$ & & 0.93 & & & Max 0.33 , average 0.29 & $0.07 \sim 0.22$ & $0.014 \sim 0.0 .019$ \\
\hline \multirow{7}{*}{ Ore block III } & & & $\begin{array}{c}\text { Concealed } \\
\text { mineralization body }\end{array}$ & & 0.89 & & & Average 0.32 & Average 0.30 & Average 0.017 \\
\hline & & & Concealed ore body & 240 & $0.68 \sim 2.15$ & & & Max 0.39 , average 0.29 & $0.06 \sim 0.20$ & $0.012 \sim 0.018$ \\
\hline & & & $\begin{array}{c}\text { Concealed } \\
\text { industrial ore body }\end{array}$ & 320 & $0.39 \sim 2.58$ & & & Max 0.48 , average 0.32 & $0.10 \sim 0.36$ & $0.015 \sim 0.023$ \\
\hline & & & Concealed ore body & 80 & $0.75 \sim 1.16$ & & & Max 0.31 , average 0.26 & $0.07 \sim 0.14$ & $0.016 \sim 0.019$ \\
\hline & & & Concealed ore body & 80 & 6.90 & & & Max 0.28 , average 0.23 & $\begin{array}{c}\text { Max } 0.32, \\
\text { average } 0.22\end{array}$ & $\begin{array}{c}\text { Max 0.018, } \\
\text { average } 0.016\end{array}$ \\
\hline & \multirow[t]{2}{*}{ M10 } & G-M10 & $\begin{array}{c}\text { Concealed } \\
\text { industrial ore body }\end{array}$ & 80 & 2.33 & & & Max 1.06, average 0.69 & $0.03 \sim 0.36$ & $0.011 \sim 0.057$ \\
\hline & & D-M10 & Concealed ore body & 80 & 6.89 & & & Max 0.65 , average 0.25 & $0.04 \sim 0.37$ & $0.01 \sim 0.032$ \\
\hline
\end{tabular}



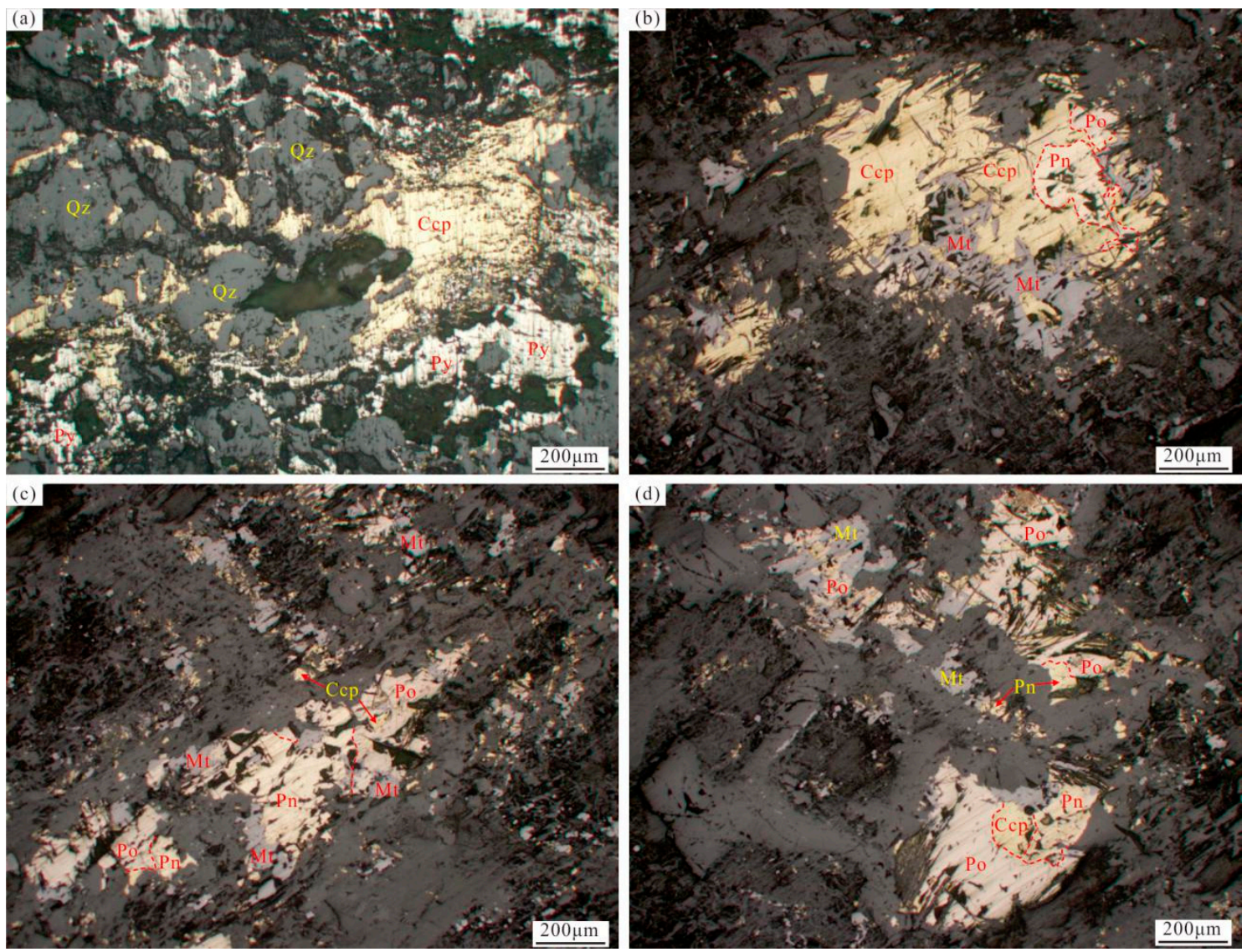

Figure 5. Representative microphotographs showing the sulfides assemblage and their paragenetic relationship in the Niubiziliang Ni-(Cu) deposit. (a) $\mathrm{Ccp}+\mathrm{Qz}$ assemblage in the G-M1 ore body; (b) $\mathrm{Ccp}+\mathrm{Po}+\mathrm{Pn}$ assemblage with $\mathrm{Mt}$ in the G-M1 ore body; (c) $\mathrm{Pn}+\mathrm{Po}+\mathrm{Ccp}$ assemblage with Mt in the G-M10 ore body; (d) Po+Pn+Ccp assemblage with Mt in the M7 ore body. Ccp, chalcopyrite; Qz, quartz; Pn, pentlandite; Po, pyrrhotite; Mt, magnetite; Py, pyrite.

Pentlandite is the most important Ni-bearing mineral in Niubiziliang and provides the majority of $\mathrm{Ni}$ resources. It usually occurs in the inner or outer margin of pyrrhotite in the form of xenomorphic-hypidiomorphic aggregates with a minor hypidiomorphic granularity in gangue minerals, with a size of about $0.1 \sim 0.5 \mathrm{~mm}$ (Figure $5 \mathrm{~b}-\mathrm{d}$ ).

Chalcopyrite in Niubiziliang mainly occurs in the following two forms: (a) Coexisting with pyrite (Figure 5a), and (b) coexisting with pentlandite and pyrrhotite (Figure 5b-d). The former chalcopyrite is mainly hosted in the GM-1 Ni-Cu ore body in disseminated, crumby, or massive forms, whereas the latter is mainly distributed in the remaining $\mathrm{Ni}-(\mathrm{Cu})$ ore/mineralization bodies in dissemination, dropwise, or veinlet forms.

The original sulfide ore is the most important ore in the Niubiziliang Ni-(Cu) deposit, with a few oxidized ores. It is generally composed of pyrite, pyrrhotite, chalcopyrite, and pentlandite, and can be divided into disseminated ( $<20 \%$ sulfides), sideronitic (20 40\% sulfides), vein-like (10 30\% sulfides), crumby ( $40 \sim 60 \%$ sulfides), and massive ( $>60 \%$ sulfides) types. The ore texture is mainly a xenomorphic granular texture, xenomorphic intersertal texture, and sideronitic texture, and the disseminated structure, vein structure, and massive structure are the main ore structures in the Niubiziliang deposit. In fact, the formation of different types of ore is closely related to the magma exhibiting variable sulfide melting.

A disseminated ore is usually composed of $<20 \%$ sulfides, being the main type of ore in Niubiziliang. The sulfides in the disseminated ore are mainly pyrrhotite, pentlandite, and chalcopyrite, with a few pyrites and magnetites (Figure 5c), in which pyrrhotite, pentlandite, and chalcopyrite often coexist. 
A disseminated ore becomes a sideronitic ore when the sulfide content reaches $20 \sim 40 \%$ and sulfides are often filled between the silicate minerals in the form of a xenomorphic assemblage. The sideronitic ore mainly occurs in the M10 Ni-(Cu) ore body, which means that its Ni grade is higher than that of other ore/mineralization bodies.

A crumby and massive ore usually contains $>60 \%$ sulfides and is mainly hosted in the GM-1 $\mathrm{Ni}-\mathrm{Cu}$ ore body, which provides the majority of Ni resources of Niubiziliang, with the highest grade of Ni of $1.57 \%$. The GM-1 Ni-Cu ore body contains many pyrites, in addition to the Po $+\mathrm{Pn}+\mathrm{Ccp}$ assemblage, and chalcopyite is often associated with pyrite (Figure 5a), which is quite different from other ore/mineralization bodies.

\subsection{Samples and Petrography}

The Niubiziliang mafic-ultramafic complex can be divided into mafic to ultramafic rocks, and is comprised of peridotites, pyroxenites, and gabbros. The gabbro is widely distributed, constituting the main part of the complex, and is then intruded by the peridotite, pyroxenite, and post-mineralization diorite and granite. The probable emplaced sequence of the mafic-ultramafic rocks is gabbro $\rightarrow$ pyroxenite $\rightarrow$ peridotite, according to a large number of rock core data. Harzburgite is the most important ore-hosted rock, while the mineralization of gabbro is weak, with a few pyrites occurring locally. The mafic-ultramafic rocks in Niubiziliang mainly contain harzburgite, olivine pyroxenite, lherzolite, olivine websterite, hornblende lherzolite, pyroxenite, websterite, olivine gabbro, melagabbro, bojite, and gabbro (Figure 6).
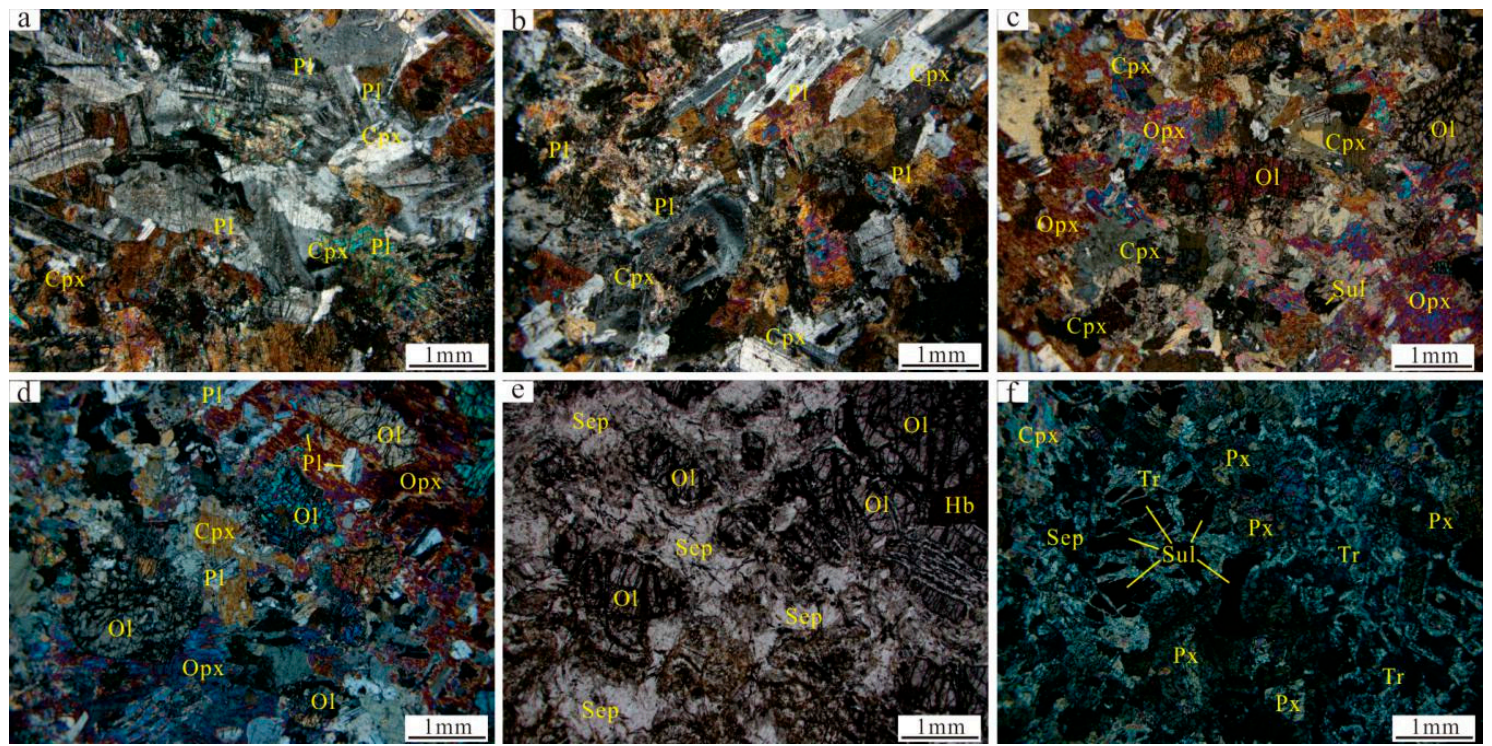

Figure 6. Representative microphotographs of mafic-ultramafic rocks in the Niubiziliang Ni-(Cu) deposit. (a) Gabbro; (b) Melagabbro; (c) Websterite with sulfides; (d) Olivine pyroxenite; (e) Harzburgite with serpentinization; (f) Harzburgite with sulfides and serpentinization, talcitization. Pl, plagioclase; Cpx, clinopyroxene; Ol, olivine; Opx, orthopyroxene; Sep, serpentine; Hb, hornblende; Sul, sulfide; Tr, tremolite; Px, pyroxene.

The gabbro is gray in color, has a gabbro texture, and is massive, and mainly contains clinopyroxene (40\%), plagioclase (55\%), and hornblende (5\%) (Figure 6a). The plagioclase is euhedral clintheriform, measuring $1.0 \sim 1.5 \mathrm{~mm}$, with a weak alteration. The pyroxene is mainly filled between the plagioclases in the form of a xenomorphic-hypidiomorphic granularity, with a size of about $1.0 \mathrm{~mm}$. In addition, there are a few banded gabbros in the No. I ore block, and the pyroxenes and plagiaclases occur in band and alternation, which indicates the in situ fractional crystallization and cumulation of mafic minerals in the diagenic process. 
Melagabbro is grayish-black in color, has a gabbro texture, and is massive, and mainly contains pyroxene $(70 \%)$, plagioclase $(25 \%)$, and hornblende $(5 \%)$ (Figure $6 \mathrm{~b})$. The pyroxene is mainly clinopyroxene $(80 \%)$ and xenomorphic-hypidiomorphic granular in shape, with a size of $0.50 \sim 2.0 \mathrm{~mm}$. The plagiaclase is often filled between the pyroxene in the form of a xenomorphic-hypidiomorphic granularity, with a size of $0.2 \sim 3.0 \mathrm{~mm}$. The plagioclase is euhedral clintheriform, measuring $1.0 \sim 1.5 \mathrm{~mm}$, with weak alteration.

The websterite is black in color, has a stacking texture, and is massive, and is mainly composed of orthopyroxene $(50 \%)$, clinopyroxene $(35 \%)$, olivine $(8 \%)$, plagiaclase $(5 \%)$, and opaque mineral $(2 \%)$ (Figure $6 \mathrm{c})$. The orthopyroxene $(70 \%)$ and clinopyroxene are usually xenomorphic-hypidiomorphic granular in shape, with a size of $0.5 \sim 1.5 \mathrm{~mm}$, and enclose the olivine. The olivine is rotund in shape and $0.3 \sim 1.0 \mathrm{~mm}$ in size, with cleavage and high protuberance.

The olivine pyroxenite is black in color, has a granular texture, and is massive, and is mainly composed of pyroxene (50\%), olivine $(40 \%)$, hornblende $(5 \%)$, and plagioclase $(5 \%)$ (Figure $6 \mathrm{~d}$ ). The pyroxenes are mainly composed of orthopyroxene (70\%) and clinopyroxene $(30 \%)$, and they have a xenomorphic-hypidiomorphic granularity, with a size of $0.5 \sim 1.5 \mathrm{~mm}$. The olivine is rotund in shape and $0.3 \sim 1.0 \mathrm{~mm}$ in size, with cleavage and high protuberance, and has been serpentinized and talcolized. The hornblende is brownish in color, $0.5 \sim 2.0 \mathrm{~mm}$ in size, and filled between the pyroxene and olivine grains in the form of xenomorphic granularity.

The harzburgite is black in color, granular, and massive, and is mainly composed of olivine $(60 \%)$, orthopyroxene $(30 \%)$, clinopyroxene $(5 \%)$, and opaque mineral $(5 \%)$, with strong alteration (Figure $6 \mathrm{e}, \mathrm{f})$. The olivine is rotund in shape and 1 2 $\mathrm{mm}$ in size, with cleavage and high protuberance, and has been serpentinized and talcolized. The orthopyroxene has a xenomorphic-hypidiomorphic granularity, with a size of $1.5 \sim 3.0 \mathrm{~mm}$, and most of it is altered into tremolite and talc. The opaque minerals are mainly pyrrhotite, chalcopyrite, and pentlandite.

\section{Analytical Methods}

\subsection{Electron Microprobe Analysis}

A total of eight samples (e.g., harzburgite, websterite, olivine pyroxenite, olivine gabbro, gabbro, and bojite) were selected to conduct the electron microprobe analysis for the main silicate minerals in this study. Eight polished thin sections were analyzed on a JEOL JXA8230 electron probe microanalyzer at the MLR Key Laboratory of Metallogeny and Mineral Assessment, Institute of Mineral Resources, Chinese Academy of Geological Sciences. The operating conditions were executed with an accelerating voltage of $20 \mathrm{kV}$ and a beam current of $20 \mathrm{nA}$, with a $5 \mu \mathrm{m}$ diameter beam size. The spectral lines, standards, and count times that were used and averages of detection limits are listed in Supplementary Materials Table S1, and the EMPA data of olivines, pyroxenes, plagioclases, and hornblendes presented in this paper are all shown in Tables S2-S5.

\subsection{Sulfide S-Pb Isotope Analysis}

A total of twelve sulfides (i.e., pyrite, pentlandite, and pyrrhotite) were selected from the massive and disseminated ores in the No. II and III ore blocks for S and Pb isotope analyses, and were tested at the Beijing Research Institute of Uranium Geology. A Finnigan MAT 251 mass spectrometer was utilized to analyze the $S$ isotopic compositions and the uncertainty was $\pm 0.2 \%$ o for $\delta^{34} S_{\mathrm{V}-\mathrm{CDT}}$. The reported data are relative to Vienna Canon Diablo Troilite (V-CDT) sulfide. As for the Pb-isotopic compositions of sulfides, $50 \mathrm{mg}$ of powder was dissolved in a mixed solution of hydrofluoric and perchloric acid, followed by elution through anion exchange resin, in order to separate $\mathrm{Pb}$. The $\mathrm{Pb}$ isotopic compositions were measured on an ISOPROBE-T Thermal Ionization Mass Spectrometer with the NBS SRM 981 standard. The precisions for ${ }^{204} \mathrm{~Pb} /{ }^{206} \mathrm{~Pb}$ and ${ }^{208} \mathrm{~Pb} /{ }^{206} \mathrm{~Pb}$ ratios were better than 0.005 , and the results are listed in Tables 2 and 3. 
Table 2. The sulfur isotopes of sulfides from the Niubiziliang mafic-ultramafic complex.

\begin{tabular}{cccccc}
\hline Sample & Rock Type & Mineralization & Testting Sulfide & $\mathbf{\delta}^{34} \mathbf{S}(\% \mathbf{o})$ & Reference \\
\hline NBZL-II-ZK0801-B1 & Harzburgite & Massive ore & Pentlandite & -1.5 & \\
NBZL-II-ZK0801-B11 & Lherzolite & Massive ore & Pentlandite & -0.8 & \\
NBZL-III-ZK0801-B20 & Olivine pyroxenite & Disseminated ore & Pyrrhotite & 3.9 & This paper \\
& & Pyrite & 1.4 & \\
NBZL-III-ZK0801-B21 & Websterite & Disseminated ore & Pentlandite & 3.7 & \\
NBZL-III-ZK0801-B22 & Olivine pyroxenite & Disseminated ore & Pyrrhotite & 0.7 & \\
\hline NS-1 & & & Pyrite & -1.4 & \\
NS-2 & & Pyrite & -1.8 & \\
NS-3 & & Pyrite & -0.1 & \\
NS-4 & & Pyrite & -2.8 & Ling, 2014 [22] \\
NS-5 & & Pyrite & -8.4 & \\
In-situ 1 & & Cu-Ni sulfide & 9.47 & \\
In-situ 2 & & Cu-Ni sulfide & 6.79 & \\
In-situ 3 & & Cu-Ni sulfide & 0.32 & \\
\hline
\end{tabular}

Table 3. The lead isotopes of sulfides from the Niubiziliang mafic-ultramafic complex.

\begin{tabular}{cccccc}
\hline Sample & NBZL-II-ZK0801-B11 & \multicolumn{2}{c}{ NBZL-III-ZK0801-B20 } & NBZL-III-ZK0801-B21 & NBZL-III-ZK0801-B22 \\
\hline Rock Type & Harzburgite & \multicolumn{2}{c}{ Olivine pyroxenite } & Websterite & Olivine pyroxenite \\
Testing Sulfide & Pentlandite & Pyrrhotite & Pyrite & Pyrrhotite & Pentlandite \\
${ }^{206} \mathrm{~Pb} / 04 \mathrm{~Pb}$ & 21.359 & 18.153 & 18.334 & 17.958 & 19.574 \\
${ }^{207} \mathrm{~Pb} / 04 \mathrm{~Pb}$ & 16.161 & 15.604 & 15.655 & 15.549 & 15.819 \\
${ }^{208} \mathrm{~Pb} / 04 \mathrm{~Pb}$ & 42.379 & 38.265 & 38.610 & 38.363 & 40.108 \\
${ }^{206} \mathrm{~Pb} / 07 \mathrm{~Pb}$ & 1.3216 & 1.1634 & 1.1711 & 1.1549 & -4374 \\
$\mathrm{t}(\mathrm{Ma})$ & -1000 & 357.8 & 289.5 & 432.3 & 9.79 \\
$\mu$ & 10.65 & 9.50 & 9.58 & 9.42 & 38.88 \\
$\omega$ & 42.73 & 37.27 & 38.17 & 38.29 & 3.84 \\
$\mathrm{Th} / \mathrm{U}$ & 3.88 & 3.80 & 3.86 & 3.93 & 149.05 \\
$\mathrm{~V} 1$ & 250.93 & 67.09 & 80.21 & 64.39 & 109.59 \\
$\mathrm{~V} 2$ & 180.90 & 54.51 & 60.83 & 42.44 & 33.5 \\
$\Delta \alpha$ & 265.24 & 75.32 & 86.05 & 63.77 & 83.38 \\
$\Delta \beta$ & 55.72 & 19.34 & 22.67 & 15.74 & 87.75 \\
\hline$\gamma$ & 149.34 & 37.76 & 47.12 & 40.42 & \\
\hline
\end{tabular}

\subsection{Whole-Rock O Isotope Analysis}

Four mafic-ultramafic rock samples (i.e., harzburgite and gabbro) were obtained from the No. II and III ore blocks to conduct the $\mathrm{O}$ isotopic analysis, and were tested at the Beijing Research Institute of Uranium Geology. The whole-rock samples were reacted with pure bromine pentafluoride at $500 \sim 680{ }^{\circ} \mathrm{C}$ for $14 \mathrm{~h}$, in order to release the $\mathrm{O}_{2}$ and impurity under a vacuum condition of $10^{-3} \mathrm{~Pa}$ in the sample preparation unit. After this, the impurity components, such as $\mathrm{SiF}_{4}$ and $\mathrm{BrF}_{3}$, were separated using the freezing method, the pure $\mathrm{O}_{2}$ was reacted with graphite at a constant temperature under the condition of $700{ }^{\circ} \mathrm{C}$, and a platinum catalyst was employed to produce $\mathrm{CO}_{2} \cdot \mathrm{CO}_{2}$ was collected by using the freezing method, and the $\mathrm{O}$ isotopic composition of the whole-rock samples was analyzed by MAT253 gas isotopic mass spectrometry. The measurement results are defined as SMOW and marked as $\delta^{18} \mathrm{O}_{\mathrm{V}-\mathrm{SMOW}}$, and the analysis accuracy is better than $\pm 0.2 \%$. The reference standard for an oxygen isotope is GBW-04409 and GBW-04410 of quartz, of which $\delta^{18} \mathrm{O}$ is $11.11 \pm 0.06 \%$ ond $-1.75 \pm 0.08 \%$, respectively, and the results are listed in Table 4. 
Table 4. The whole-rock oxygen isotopes of the Niubiziliang mafic-ultramafic complex.

\begin{tabular}{ccccc}
\hline Sample & Rock Type & Mineralization & $\left.\boldsymbol{\delta}^{\mathbf{1 8}} \mathbf{O}_{\text {V-SMOW }} \mathbf{( \% o}\right)$ & Reference \\
\hline NBZL-II-DB-B8 & Harzburgite & Disseminated sulfides & 7.4 & \\
NBZL-II-DB-B9 & Harzburgite & Disseminated sulfides & 8.1 & This paper \\
NBZL-III-DB-B8 & Gabbro & Starspot pyrite locally & 6.7 & \\
NBZL-III-DB-B9 & Gabbro & Starspot pyrite locally & 7.1 & \\
\hline 401-I-G4-2 & Harzburgite & Disseminated sulfides & 6.6 & \\
401-I-G5 & Harzburgite & Disseminated sulfides & 5.1 & Ling, 2014 [22] \\
II 5-14 & Gabbro & Starspot pyrite locally & 6.8 & \\
II 5-15 & Gabbro & Starspot pyrite locally & 7.8 & \\
II 6-5 & Olivine-pyroxene hornblendite & Disseminated sulfides & 6.5 & \\
\hline
\end{tabular}

\section{Results}

\subsection{Mineral Chemistry}

\subsubsection{Olivine}

The olivine Fo values of the Niubiziliang complex are 88 89, all of which belong to chrysolite Table S2). They are slightly lower than the olivine Fo values of mantle peridotite $($ Fo $=90.8$ [23]) and island arc calc-alkaline basalt (mostly more than 90), and similar to the typical magmatic Cu-Ni sulfide deposits in China, such as Xiarihamu (Fo = 82 88 [24]), Hongqiling (Fo = 83 87 [25]), and Jinchuan (Fo = 84 84; [26]) deposits, but higher than the Fo values (79 84) obtained by Ling et al. (2014a) [3].

\subsubsection{Pyroxene}

Pyroxene mainly includes orthopyroxene and clinopyroxene (Table S3). The orthopyroxene is mainly distributed in the ultramafic rocks, being an important and symbol mineral of the ore-hosting ultramafic rocks. The En value of the orthopyroxene in Niubiziliang is 79 82, which belongs to clinoenstatite (Figure 7a), and is close to that of Xiarihamu (En = 78 86 [24]).

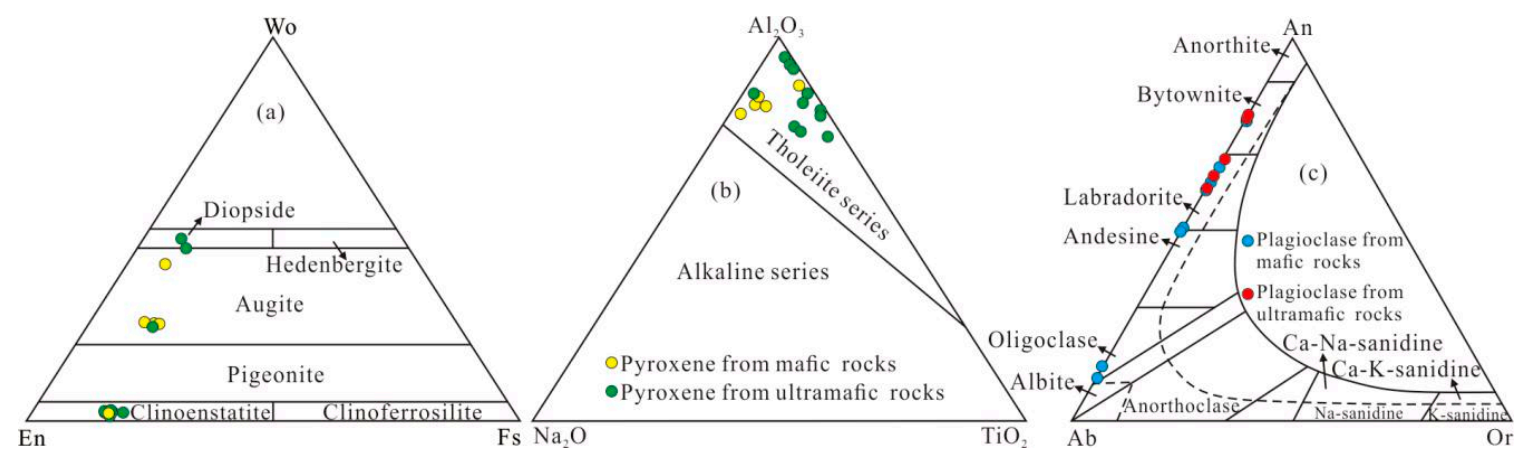

Figure 7. Wo-En-Fs diagram of pyroxenes (a) modified after Morimoto (1988) [27]); $\mathrm{Al}_{2} \mathrm{O}_{3}-\mathrm{Na}_{2} \mathrm{O}-\mathrm{TiO}_{2}$ diagram of pyroxenes (b) modified after Qiu and Liao (1996) [28]); Au-Ab-Or diagram of plagioclases (c) modified after Parsons (2010) [29]), in the Niubiziliang mafic-ultramafic complex.

The clinopyroxene mainly occurs in gabbro, bojite, and other mafic rocks often coexisting with hornblende, and the websterite and olivine pyroxenite also contain some clinopyroxenes. The clinopyroxenes mainly fall into the augite and diopside in the Wo-En-Fs diagram (Figure 7a) and fall into the tholeiite in the $\mathrm{Al}_{2} \mathrm{O}_{3}-\mathrm{Na}_{2} \mathrm{O}-\mathrm{TiO}_{2}$ diagram (Figure $7 \mathrm{~b}$ ).

\subsubsection{Plagioclase}

Plagioclase is widely distributed in all kinds of mafic-ultramafic rocks, and mainly falls into the labradorite, with some falling into bytownite and oligoclase, in the An-Ab-Or diagram (Figure 7c and Table S4). The An values for plagiaclase in ultramafic rocks are usually large, and are dominated by 
bytownite and labradorite. However, the An values for plagioclase in gabbro vary greatly, and are mainly concentrated at 50 60 (labradorite), with the minority being as low as 10 14 (oligoclase). The An values for plagioclase in ultramafic rocks are generally higher than those of mafic rocks, indicating that the An values of plagioclase are closely related to the degree of basicity of rocks.

\subsubsection{Hornblende}

The hornblende in the Niubiziliang complex mainly belongs to calcareous hornblende (Table S5). In the classification diagram of Leake et al. (1997) [30], the hornblende of olivine pyroxenite was pargasite, whereas the hornblende of basic rocks (e.g., gabbro, bojite, and melagabbro) was pargasite and tremolite (Figure 8). Hornblendes in olivine pyroxenite all have a mantle origin, while hornblendes from the basic rocks mainly have a crust origin, with some mantle origin, in the diagrams of $\mathrm{Al}_{2} \mathrm{O}_{3}-\mathrm{TiO}_{2}$ and Si-Al atoms (Figure 9). This could indicate that crustal contamination and the ultrabasic magma and mantle-origin hornblende evolved to the basic magma and crust-origin hornblende due to the addition of crustal felsic components.
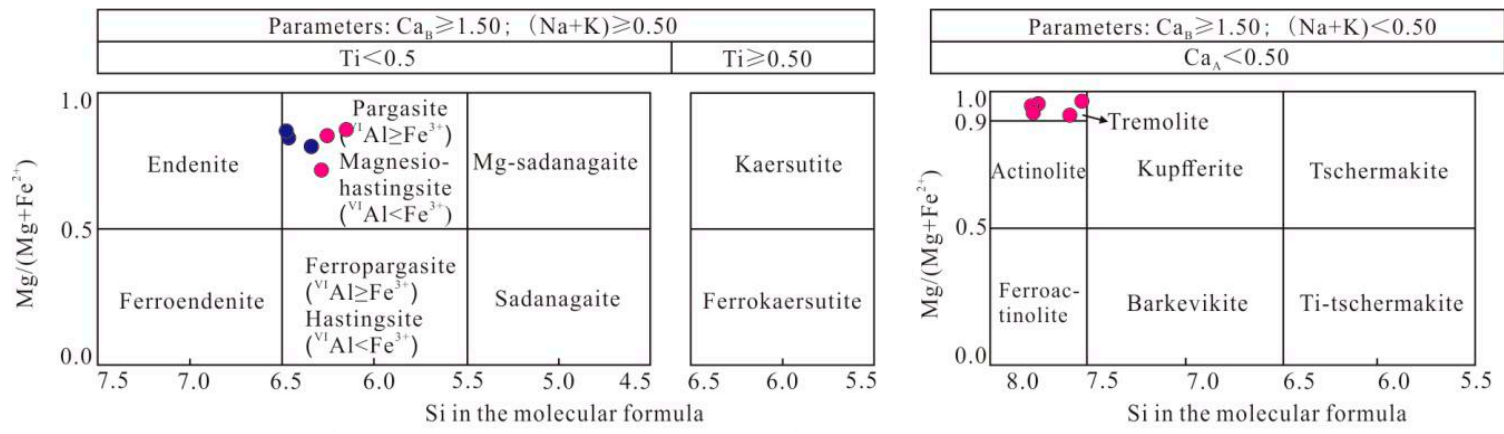

- Hornblende from mafic rocks

- Hornblende from ultramafic rocks

Figure 8. Classification diagram of calcium hornblende family in the Niubiziliang mafic-ultramafic complex (modified after Leake et al. (1997) [30]).
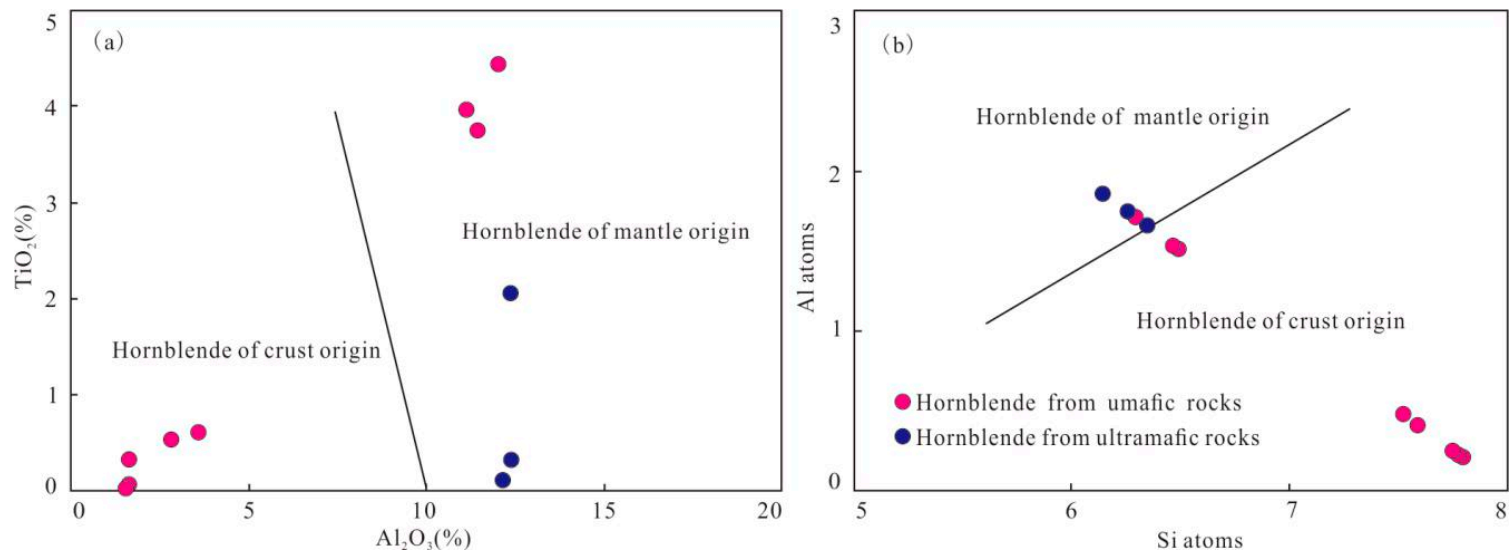

Figure 9. $\mathrm{Al}_{2} \mathrm{O}_{3}-\mathrm{TiO}_{2}(\mathbf{a})$ and $\mathrm{Si}-\mathrm{Al}$ atoms (b) diagrams of calcium hornblendes showing the mantle and crust origins, respectively, in the Niubiziliang mafic-ultramafic complex (modified after Jiang and An (1984) [31]).

\subsection{S-Pb Isotopes of Sulfide}

\subsubsection{S Isotopes}

The $\delta^{34} \mathrm{~S}$ value of the fifteen sulfides in Niubiziliang is $-8.4 \sim 9.47 \%$, with a wide range of variation (Table 2), among which eight samples are $-1.8 \sim 1.4 \%$, and thus close to that of the upper mantle $\left(0 \pm 2 \%\right.$ [32]). However, the $\delta^{34} \mathrm{~S}$ values of the remaining seven samples are $-8.4 \sim-2.8 \%$ and 3.7 9.47\%o, which are significantly different from that of the upper mantle. 


\subsubsection{Pb Isotopes}

The values of ${ }^{206} \mathrm{~Pb} /{ }^{204} \mathrm{~Pb},{ }^{207} \mathrm{~Pb} /{ }^{204} \mathrm{~Pb}$, and ${ }^{208} \mathrm{~Pb} /{ }^{204} \mathrm{~Pb}$ of the five sulfides are 17.958 21.359, 15.549 16.161, and 38.265 42.379, respectively (Table 3), with a wide range of variation. The discriminant diagrams show that the $\mathrm{Pb}$ in Niubiziliang is mainly derived from the orogenic belt, with some upper crust $\mathrm{Pb}$ (Figure 10). The $\mathrm{Pb}$ isotope of pentlandite in the No. II ore block (falling outside of Figure 10) is quite different from that of the sulfides in the No. III ore block and is abnormal Pb, which could be related to the later hydrothermal activities.
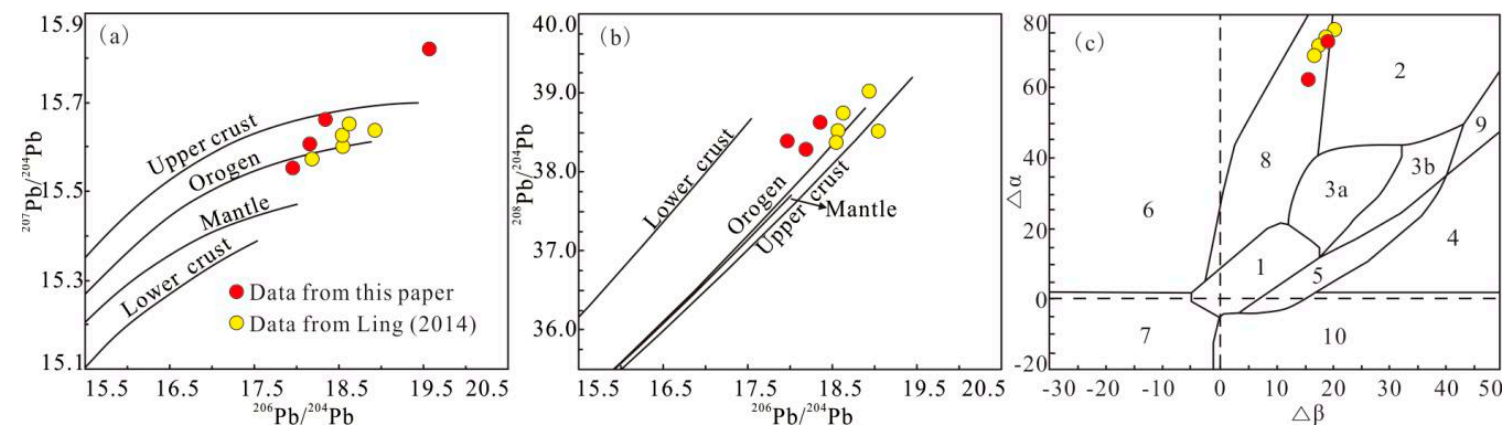

Figure 10. Diagrams of lead isotope of sulfides showing a mixing lead with majority coming from the orogen in the Niubiziliang Ni-(Cu) deposit (modified after Zartman and Doe (1981) [33]). 1, mantle; 2 , upper crust; 3, magmatism in subduction zone; $3 \mathrm{~b}$, sedimentation in subduction zone; 4 , chemically deposition; 5, submarine hot-water; 6, mesometamorphism; 7, hypometamorphism in lower crust; 8 , orogen; 9 , ancient shale in upper crust; 10, retrometamorphism. (a) Coming from the orogen and upper crust; (b) Coming from the orogen; (c) Coming from the orogen.

\subsection{Whole-Rock O Isotopes and S/Se Ratios}

\subsubsection{O Isotopes}

The $\delta^{18} \mathrm{O}$ value of the four samples employed in this study is $6.7 \sim 8.1 \%$, with a wide range of variation (Table 4), which is close to the data obtained by Ling et al. (2014) [13] $\left(\delta^{18} \mathrm{O}=5.1 \sim 7.8 \%\right.$ o). Therefore, all of the samples have higher values than the $\delta^{18} \mathrm{O}$ value of the mantle, except for one sample, which is close to the mantle.

\subsubsection{S/Se Ratios}

The S/Se value of five samples from the Niubiziliang complex is 1864 5890, most of which are higher than that of the mantle (Table 5). One sample is in the mantle region, another is in the $S$ loss region, and those remaining are in the $S$ addition region (Figure 11).

Table 5. Concentrations of S, Se, and Te from the Niubiziliang mafic-ultramafic complex.

\begin{tabular}{cccccc}
\hline Sample & Rock Type & S(ppm) & Se(ppm) & Te(ppm) & S/Se \\
\hline NBZL-II-ZK0302-B15 & Harzburgite & 1845 & 0.36 & 0.06 & 5185 \\
NBZL-II-DB-B14 & Gabbro & 615 & 0.33 & 0.04 & 1864 \\
NBZL-III-ZK0801-B20 & Olivine pyroxenite & 1640 & 0.31 & 0.04 & 5230 \\
NBZL-III-ZK0801-B21 & Websterite & 4100 & 1.04 & 0.06 & 3927 \\
NBZL-III-ZK0801-B22 & Olivine pyroxenite & 2665 & 0.45 & 0.05 & 5890 \\
\hline
\end{tabular}




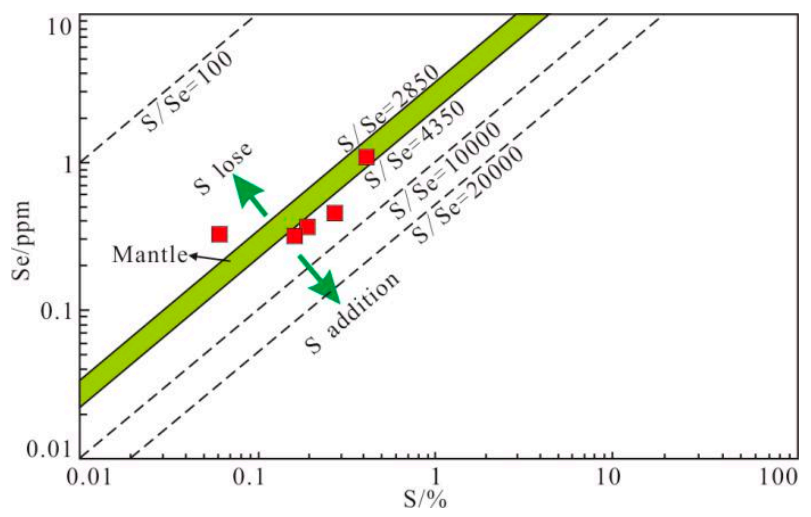

Figure 11. Contamination diagram of S-Se showing an extra sulfur adding to the magma in the Niubiziliang Ni-(Cu) deposit (modified after Smith et al. (2016) [34]).

\section{Discussion}

\subsection{Parental Magma}

Previous studies have shown that the distribution coefficient of $\mathrm{Mg}$-Fe between peridotite and melt was a relatively stable value, that is, $\mathrm{Kd}$ Ol-Melt $=(\mathrm{TFeO} / \mathrm{MgO})_{\mathrm{Ol}} /\left(\mathrm{TFeO} / \mathrm{MgO}_{\mathrm{mag}}\right)=0.3 \sim 0.33[35,36]$. The $\mathrm{MgO} / \mathrm{TFeO}$ value of the melt coexisting with olivine in this study was obtained by using the above formula, resulting in a value of 1.37 1.51 (choosing $\mathrm{Fo}_{\max }=89$ for olivine), which was lower than that of the whole-rock geochemistry $(\mathrm{MgO} / \mathrm{TFeO}=2.36 \sim 2.98)$; selecting the whole-rock geochemistry data from Yu et al. (2019) [16] in the Niubiziliang complex. Therefore, the analyzed results in this study could not represent the coexisting melt components, and there were excess olivines adding to the pre-emplaced magma, implying that the pre-emplaced magma is a derivative magma that has undergone deep olivine crystallization by the parental magma. Meanwhile, the $\mathrm{NiO}$ content of olivine $(0.10 \sim 0.23 \%)$ in this study was significantly lower than that of olivine $(\approx 0.4 \%$ [24] $)$ crystallized from the primitive basaltic magma, which equilibrated with pyrolite. This indicates that the magma of the Niubiziliang complex is derivative magma from which the parental magma underwent differentiation and resulted in strong $\mathrm{NiO}$ depletion. Additionally, all of the samples are located below the curve

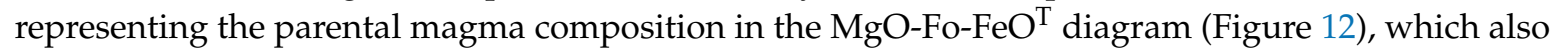
indicates the addition of extra olivine.

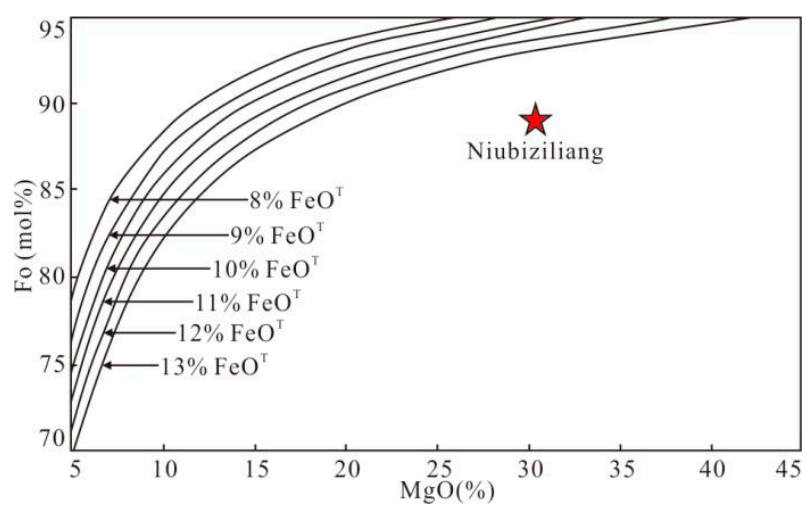

Figure 12. $\mathrm{MgO}-\mathrm{Fo}-\mathrm{FeO}$ diagram of harzburgite showing an excess of olivine adding to the magma in the Niubiziliang Ni-(Cu) deposit (modified after Zhang and Wang (2003) [37]). The MgO value in abscissa takes the mean value of $\mathrm{MgO}$ content in the whole-rock geochemistry of the corresponding sample and assumes the distribution coefficient of 0.3 .

Therefore, the $\mathrm{MgO}$ content of parental magma was estimated to be $16.58 \%$ by using the formula of $w_{\mathrm{MgO}}=[0.56095 \times \mathrm{Kd} \times \mathrm{Fo} /(1-\mathrm{Fo})] \times w_{\mathrm{TFeO}}\left(\mathrm{Kd}=0.3, \mathrm{FeO}^{\mathrm{T}}=12.18 \%, \mathrm{Fo}=89 ;[35]\right)$. Meanwhile, 
the $\mathrm{MgO}$ and $\mathrm{FeO}^{\mathrm{T}}$ contents of the parental magma could also be estimated to be $14.9 \%$ and $13.43 \%$,

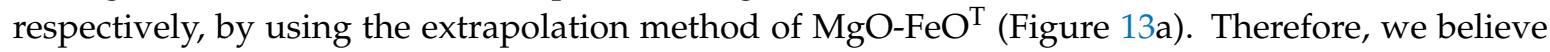
that the $\mathrm{MgO}$ content of the parental magma is about $14.95 \sim 16.58 \%$, which is higher than the value $(\mathrm{MgO}=10.8 \%)$ estimated previously by Ling et al. (2014a) [13], and the corresponding $\mathrm{FeO}^{\mathrm{T}}$ content is about $13.43 \sim 14.89 \%$. The difference mainly reflects the different Fo value of olivine in the samples used in the calculations. The Fo value of olivine in harzburgite samples chosen by Ling et al. (2014a) [13] was 84, which was five lower than in the samples used in this study. It resulted in a low MgO content, a large error in the composition of the parental magma, and a low degree of partial melting of the mantle. The $\mathrm{MgO}$ content of parental magma in Niubiziliang is significantly higher than that of Jinchuan (12.6\% [38]) and Xiarihamu (12.48\% [24] and 12.74\% [39]), and the NiO content in it could be estimated to be $0.053 \sim 0.068 \%$ by using the discrimination diagram of $\mathrm{MgO}-\mathrm{NiO}$ (Figure 13b). Meanwhile, the $\mathrm{Mg}^{\#}$ value of parental magma was calculated to be 71 by the formula of $\mathrm{Mg}^{\#}=1 /(1+(1-\mathrm{Fo}) /(\mathrm{Kd} \times \mathrm{Fo}))$ $(\mathrm{Kd}=0.3, \mathrm{Fo}=89)$, which is close to the $\mathrm{Mg}^{\#}$ value of primary basaltic magma. Therefore, the parental magma of the Niubiziliang complex is considered to be high-Mg picritic basalt, which also suggests high-degree melting of depleted mantle $\left(\varepsilon_{\mathrm{Hf}(\mathrm{t})}=4.2 \sim 10.9\right.$ [16]).
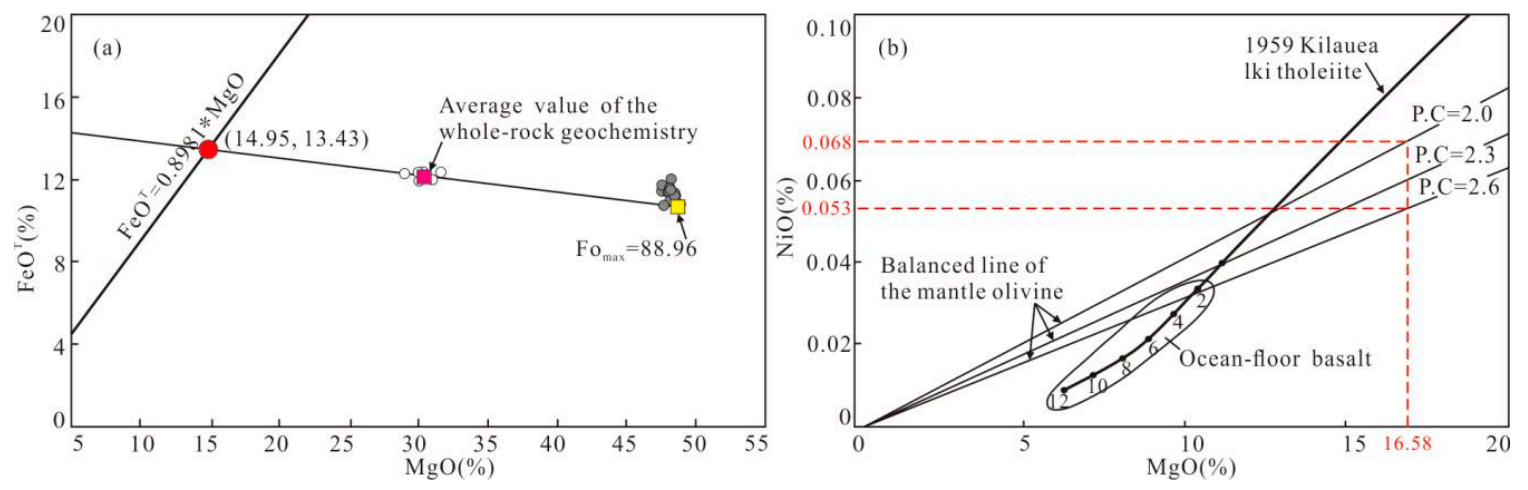

Figure 13. $\mathrm{MgO}-\mathrm{FeO}^{\mathrm{T}}$ diagrams of extrapolation method for primary magma estimation (a) modified after Tao et al. (2002) [40]); MgO-NiO diagram of magma composition in equilibrium with mantle peridotite during fractional crystallization of primary magma (b) modified after Sato (1977) [41]), in the Niubiziliang Ni-(Cu) deposit.

\subsection{Estimation of Mineral Crystallization Conditions}

\subsubsection{Olivine}

The crystallization temperature of olivine is generally calculated by the geological thermometer formula of $\mathrm{T}\left({ }^{\circ} \mathrm{C}\right)=1056.6+17.3 \times \mathrm{MgO} \pm 26$ [42], where the $\mathrm{MgO}$, here, presents its content in parental magma. Therefore, the crystallization temperature of olivine in Niubiziliang was calculated to be $1289 \sim 1369^{\circ} \mathrm{C}$ by the geological thermometer formula above. Meanwhile, the $\mathrm{CaO}$ content of olivine was low $(0 \sim 0.35 \%)$, indicating a high crystallization pressure [43], that it had crystallized in the magma chamber, and that olivine is frequently surrounded by pyroxene in a round shape to form a poikilitic texture.

\subsubsection{Pyroxene}

Since orthopyroxene and clinopyroxene widely existed in the Niubiziliang mafic-ultramafic complex, two-pyroxene thermobarometry proposed by Putirka (2008) [44] was very appropriate for estimating their crystallization temperature and pressure. Firstly, we used the T-independent equation of $\mathrm{P}(\mathrm{kbar})=-279.8+293 \mathrm{X}_{o p x_{\mathrm{Al}(\mathrm{VI})}}+455 \mathrm{X}_{o p x_{\mathrm{Na}}}+299 \mathrm{X}_{o p x_{\mathrm{Cr}}}+519 \mathrm{X}_{o p x_{\mathrm{Fm} 2} 2} \mathrm{Si}_{2} \mathrm{O}_{6}-563 \mathrm{X}_{o p x_{\mathrm{En}}}+$ $371 \mathrm{X}_{o p x_{\mathrm{Di}}}+372 \alpha_{o p x_{\mathrm{En}}}+1.19 / \mathrm{K}_{f}$ to obtain the crystallization pressure of ortho- and clinopyroxene for the two groups, as follows: $1.76 \sim 2.89 \mathrm{kbar}$ (average $2.30 \mathrm{kbar}$ ) and 9.38 9.67 kbar. The $\mathrm{K}_{f}=\mathrm{X}_{o p x_{\mathrm{Ca}}} /$ $\left(1-\mathrm{X}_{c p x_{\mathrm{Ca}}}\right)$ is as in Mercier et al. (1984) [45]; $\mathrm{Fm}_{2} \mathrm{Si}_{2} \mathrm{O}_{6}{ }^{o p x}=\mathrm{EnFs}^{o p x}, \mathrm{X}_{o p x_{\mathrm{En}}}=\left(\mathrm{X}_{o p x_{\mathrm{Fm}^{2}} \mathrm{Si}_{2} \mathrm{O}_{6}}\right)\left(\mathrm{X}_{o p x_{\mathrm{Mg}}} /\left[\mathrm{X}_{o p x_{\mathrm{Mg}}}\right.\right.$ 
$\left.\left.+\mathrm{X}_{o p x_{\mathrm{Mn}}}+\mathrm{X}_{o p x_{\mathrm{Fe}}}\right]\right), \mathrm{X}_{o p x_{\mathrm{Di}}}=\left(\mathrm{X}_{o p x_{\mathrm{CaFm}^{2}} \mathrm{Si}_{2} \mathrm{O}_{6}}\right)\left(\mathrm{X}_{o p x_{\mathrm{Mg}}} /\left[\mathrm{X}_{o p x_{\mathrm{Mg}}}+\mathrm{X}_{o p x_{\mathrm{Mn}}}+\mathrm{X}_{o p x_{\mathrm{Fe}}}\right]\right) ; \alpha_{o p x_{\mathrm{En}}}=\left(0.5 \mathrm{X}_{o p x_{\mathrm{Mg}}} /\left(\mathrm{X}_{o p x_{\mathrm{Ca}}}\right.\right.$ $\left.\left.+0.5 \mathrm{X}_{o p x_{\mathrm{Mg}}}+0.5 \mathrm{X}_{o p x_{\mathrm{Fe}}^{2+}}+\mathrm{X}_{o p x_{\mathrm{Mn}}}+\mathrm{X}_{o p x_{\mathrm{Na}}}\right)\right) \times\left(0.5 \mathrm{X}_{o p x_{\mathrm{Mg}}} /\left(0.5 \mathrm{X}_{o p x_{\mathrm{Fe}} 2+}+\mathrm{X}_{o p x_{\mathrm{Fe}}^{3+}}+\mathrm{X}_{o p x_{\mathrm{Al}(\mathrm{VI})}}+\mathrm{X}_{o p x_{\mathrm{Ti}}}+\right.\right.$ $\left.\mathrm{X}_{o p x_{\mathrm{Cr}}}+0.5 \mathrm{X}_{o p x_{\mathrm{Mg}}}\right)$ ), and here, $\mathrm{X}_{o p x_{\mathrm{Fe}^{2+}}}=\mathrm{X}_{o p x_{\mathrm{Fe}}}-\mathrm{X}_{o p x_{\mathrm{Fe}^{3+}}}$, where $\mathrm{Fe}^{3+}$ was calculated as in Papike et al. (1974) [46], i.e., $\mathrm{Fe}^{3+}=\mathrm{Al}^{\mathrm{IV}}+\mathrm{Na}-\mathrm{Al}^{\mathrm{VI}}-\mathrm{Cr}-2 \mathrm{Ti}$. Secondly, their corresponding crystallization depth was calculated to be $6.65 \sim 10.92 \mathrm{~km}$ (average $8.7 \mathrm{~km}$ ) and $35.45 \sim 36.55 \mathrm{~km}$ using the equation $\mathrm{d}(\mathrm{km})=100 \times \mathrm{P}(\mathrm{kbar}) /(\rho \mathrm{g})$, where $\rho$ is $2.7 \mathrm{~g} / \mathrm{cm}^{3}$ for the average basement of Jinshuikou Group gneiss. In addition, the $\mathrm{Al}^{\mathrm{IV}} /\left(\mathrm{Al}^{\mathrm{IV}}+\mathrm{Al}^{\mathrm{VI}}\right)$ value of clinopyroxene was $0.32 \sim 0.78$, with an average of 0.56 , indicating the relatively low crystallization pressure [47]. This further suggested that clinopyroxene likely crystallized after the magma intruded the existing space and its fractional crystallization was not remarkable. Therefore, we suggest that $6.65 \sim 10.92 \mathrm{~km}$ could be the invaded depth of the Niubiziliang mafic-ultramafic complex, while $34.45 \sim 36.55 \mathrm{~km}$ likely presents the depth of the magma chamber. Finally, we calculated the crystallization temperatures of ortho- and clinopyrexene to be $1185 \sim 1335^{\circ} \mathrm{C}$, with an average of $1253^{\circ} \mathrm{C}$, by using the thermometer of $10^{4} / \mathrm{T}\left({ }^{\circ} \mathrm{C}\right)=11.2-1.96 \ln \left(\mathrm{X}_{c p x_{\mathrm{EnFs}}} / \mathrm{X}_{o p x_{\mathrm{EnFs}}}\right)-$ $3.3 \mathrm{X}_{c p x_{\mathrm{Ca}}}-25.8 \mathrm{X}_{c p x_{\mathrm{CrCaTs}}}+33.2 \mathrm{X}_{o p x_{\mathrm{Mn}}}-23.6 \mathrm{X}_{o p x_{\mathrm{Na}}}-2.08 \mathrm{X}_{o p x_{\mathrm{En}}}-8.33 \mathrm{X}_{c p x_{\mathrm{Di}}}-0.05 \mathrm{P}(\mathrm{kbar})$ [44], which is slightly lower than that of olivine.

\subsubsection{Hornblende}

The thermometer of $\mathrm{T}\left({ }^{\circ} \mathrm{C}\right)=-151.487 \times \mathrm{Si}^{*}+2041$ proposed by Ridolfi et al. (2009) [37] is one of the most widely used and precise thermometers for estimating the crystallization temperature of hornblende. Here, $\mathrm{Si}^{*}=\mathrm{Si}+\mathrm{Al}^{\mathrm{IV}} / 15-2 \mathrm{Ti}-\mathrm{Al} / 2+\mathrm{Ti} / 1.8+\mathrm{Fe}^{3+} / 9+\mathrm{Fe}^{2+} / 3.3+\mathrm{Mg} / 26+\mathrm{Ca}_{\mathrm{B}} / 5+\mathrm{Na}_{\mathrm{B}} / 1.3$ $-\mathrm{Na}_{\mathrm{A}} / 15+\mathrm{K}_{\mathrm{A}} / 2.3$, where cations in this thermometer are calculated using 23 standard oxygen atoms. The crystallization temperature of hornblende, except for tremolite, in Niubiziliang was calculated to be $1098 \sim 1234{ }^{\circ} \mathrm{C}$, with an average of $1159^{\circ} \mathrm{C}$. Secondly, we used the calcareous amphibole formula of $\mathrm{P}(\mathrm{kbar})=19.209 \times e^{1.438 \mathrm{Al}(\mathrm{Tot})} / 100[48]$, where $\mathrm{Al}(\mathrm{Tot})=\mathrm{Al}^{\mathrm{IV}}+\mathrm{Al}^{\mathrm{VI}}$, to estimate the crystallization pressure of hornblende, except for tremolite, resulting in a value of $1.68 \sim 2.77 \mathrm{kbar}$, with an average of $2.15 \mathrm{kbar}$. Moreover, we also calculated the crystallization depth by applying the physical equation for the gravitational pressure of $\mathrm{d}(\mathrm{km})=100 \times \mathrm{P}(\mathrm{kbar}) /(\rho \mathrm{g})$, where $\rho$ is $2.7 \mathrm{~g} / \mathrm{cm}^{3}$ for the average basement of Jinshuikou Group gneiss. Therefore, it could be estimated that the crystallization depth of hornblende in the Niubiziliang complex is about $6.35 \sim 10.47 \mathrm{~km}$, with an average of $8.13 \mathrm{~km}$.

According to the crystallization temperature mentioned above, the crystallization sequence of silicate minerals in Niubiziliang is as follows: Olivine $\rightarrow$ orthopyroxene $\rightarrow$ clinopyroxene(plagioclase) $\rightarrow$ hornblende. This is consistent with the observation results under the microscope, and reflects the mineral crystallization at different temperatures, pressures, and depths. Olivines and some orthopyroxenes first crystallized in the magma chamber at a depth of $35.45 \sim 36.55 \mathrm{~km}$, with a pressure and temperature of 9.38 9.67 kbar and $1289 \sim 1369^{\circ} \mathrm{C}$, respectively, and they are the optimum mineral for restoring the parental magma. However, most of the silicate minerals crystallized in the existing space at a depth of $8.13 \sim 8.70 \mathrm{~km}$, with a pressure and temperature of $2.15 \sim 2.30 \mathrm{kbar}$ and $1159 \sim 1253^{\circ} \mathrm{C}$, respectively. Finally, the Niubiziliang complex and different kinds of mafic-ultramafic rocks formed through magmatic crystallization and crustal contamination.

\subsection{Magmatic Evolution}

\subsubsection{Fractional Crystallization}

Fractional crystallization is a geological process that occurs extensively in the process of mafic-ultramafic diagenesis and mineralization, and mainly takes place in the early stage of magmatic crystallization. Niubiziliang is a representative mafic-ultramafic complex with multiple invasions by magma in NQOB. It has complete lithofacies, diverse rock types, clear lithofacies boundaries, and a high degree of differentiation. Cumulates such as peridotite, pyroxenite, and anorthosite are all formed by the strong fractional crystallization of primitive basaltic magma in the magma chamber. Meanwhile, some banded gabbros in the No. I ore block (Figure 3a) indicate the local and relatively weak fractional 
crystallization of magma after invasion. The olivine-encircled texture and interstitial texture were developed in the Niubiziliang complex, which showed that the residual magma between olivine grains formed clinopyroxene to enclose olivine or filled spaces between olivine grains. This is the crystallized result of olivine, which crystallized in the magma chamber at $35.45 \sim 36.55 \mathrm{~km}$, and residual magma in the existing space at $8.13 \sim 8.70 \mathrm{~km}$.

At the same time, the geochemistry of mafic-ultramafic rocks also shows the significant fractional crystallization in the diagenetic process. The $\mathrm{Mg}^{\#}$ value of ultramafic rocks in Niubiziliang is 81 84 [16], which is higher than that of primary basaltic magma $(68 \sim 73$ [49,50]), suggesting that fractional crystallization occurred at an early stage. Meanwhile, the $\mathrm{NiO}$ content of olivine $(0.10 \sim 0.23 \%)$ is significantly lower than that of olivine crystallized by primitive basaltic magma, which is balanced with pyrolite $(\approx 0.4 \%$ ), also supporting magma differentiation and leading to a strong deficit of $\mathrm{Ni}$ in the parental magma. $\mathrm{SiO}_{2}$ correlates negatively with $\mathrm{MgO}$ (Figure $14 \mathrm{a}$ ), and $\mathrm{Ni}$, $\mathrm{Co}$, and $\mathrm{Cr}$ show positive correlations with $\mathrm{MgO}$ (Figure 14d-f), indicative of the crystallization of olivine, and the strong negative correlation between $\mathrm{Al}_{2} \mathrm{O}_{3}, \mathrm{CaO}$, and $\mathrm{MgO}$ reflects the fractional crystallization of plagioclase or clinopyroxene (Figure $14 \mathrm{~b}, \mathrm{c}$ ). If the magma has a significant fractional crystallization of clinopyroxene, in general, the $\mathrm{CaO} / \mathrm{Al}_{2} \mathrm{O}_{3}$ value and $\mathrm{Mg}^{\#}$ value show a positive correlation, while the $\mathrm{CaO}$ content and $\mathrm{CaO} / \mathrm{Al}_{2} \mathrm{O}_{3}$ value in the magma also decrease accordingly [51]. However, these characteristics are not clear in the Niubiziliang mafic-ultramafic rocks (Figure 14g,h), indicating that the fractional crystallization of clinopyroxene did not dominate the magma evolution. Despite this, the fractional crystallization of clinopyroxene in gabbro is quite obvious, similar to what occurs for olivine and orthopyroxene in ultramafic rocks during magma evolution (Figure 14i). Simkin et al. (1970) [43] suggested that the $\mathrm{CaO}$ content typically increased at a faster cooling rate and low pressures during olivine crystallization. However, the low $\mathrm{CaO}$ content of olivine $(<0.35 \%)$ in Niubiziliang suggests a slow rate and high-pressure (about 9.38 9.67 kbar) conditions [52], which is consistent with what was concluded due to the wide variation of the Fo value and $\mathrm{Mg}^{\#}$ of olivine. This further suggests that the magma chamber is deep (about $35.45 \sim 36.55 \mathrm{~km}$ ) and sufficiently differentiates, which is favorable for mineralization.
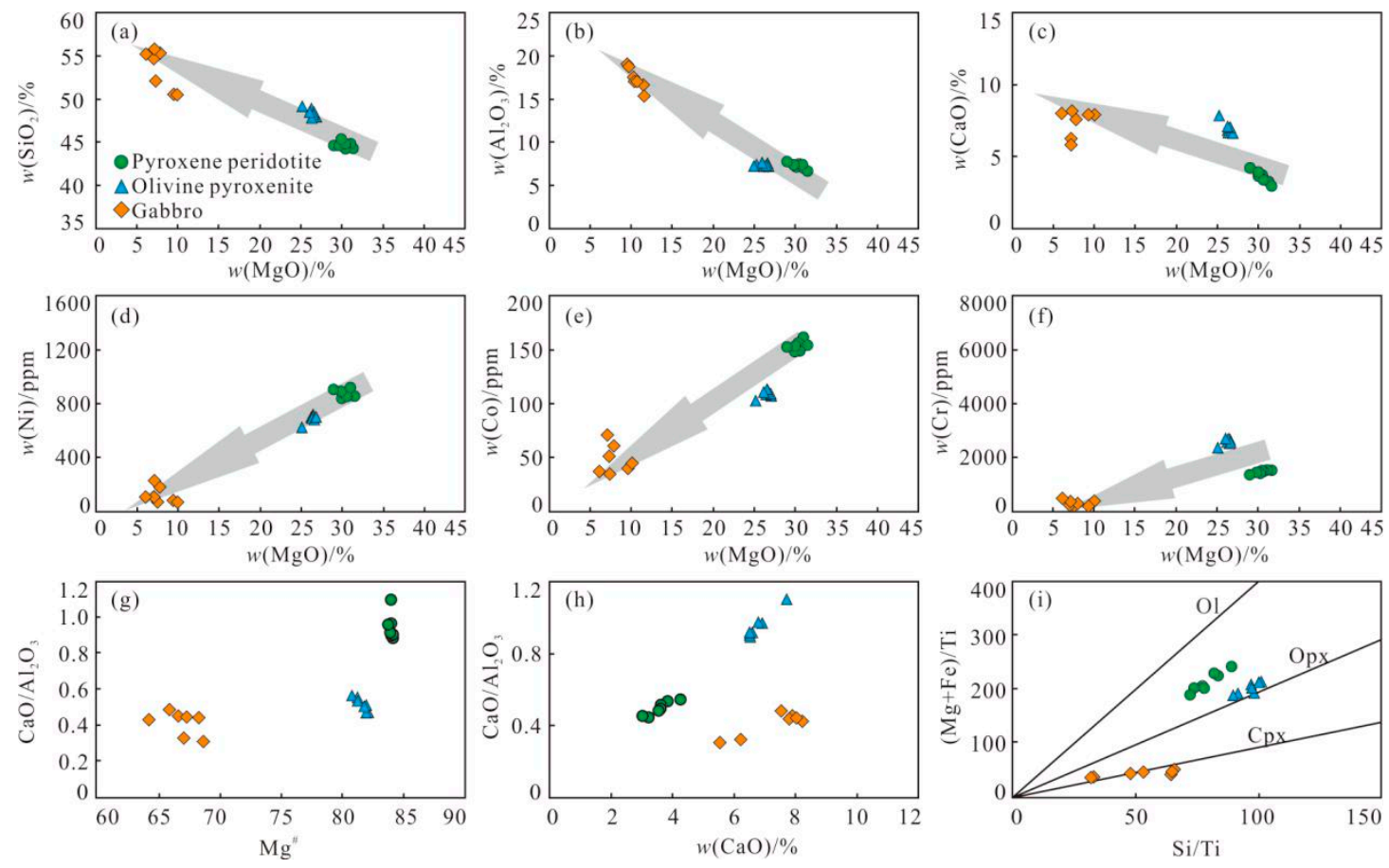

Figure 14. Geochemical diagrams of the mafic-ultramafic rocks in the Niubiziliang Ni-(Cu) deposit. (a) The negative correlation between $\mathrm{MgO}$ and $\mathrm{SiO}_{2}$; (b) The negative correlation between $\mathrm{MgO}$ and $\mathrm{Al}_{2} \mathrm{O}_{3}$; 
(c) The negative correlation between $\mathrm{MgO}$ and $\mathrm{CaO}$; (d) The positive correlation between $\mathrm{MgO}$ and $\mathrm{Ni}$;

(e) The positive correlation between $\mathrm{MgO}$ and $\mathrm{Co}$; (f) The positive correlation between $\mathrm{MgO}$ and $\mathrm{Cr}$;

(g) The discrete relationship between $\mathrm{Mg}^{\#}$ and $\mathrm{CaO} / \mathrm{Al}_{2} \mathrm{O}_{3}$; (h) The discrete relationship between $\mathrm{CaO}$ and $\mathrm{CaO} / \mathrm{Al}_{2} \mathrm{O}_{3} ;(\mathbf{i})$ The crystallizations of clinopyroxene and orthopyroxene.

\subsubsection{Crustal Assimilation and Contamination}

Crustal assimilation and contamination and fractional crystallization typically occur simultaneously during the evolution and emplacement of magma [53], and the crustal assimilation and contamination, which often occur during the formation of a large-scale $\mathrm{Ni}-\mathrm{Cu}$ deposit, are considered to be some of the key factors in the formation of a magmatic Ni-Cu sulfur deposit (Voisey's Bay [4], Jinchuan [5], Noril'sk [9], and Xiarihamu [54]). First of all, the presence of many xenoliths in the Niubiziliang complex indicates that crustal contamination inevitably occurs during the emplacement of magma. Then, the crustal contamination is not only manifested in the geology, but also usually gives several geochemical fingerprints, such as an increase of $\mathrm{SiO}_{2}, \mathrm{~K}_{2} \mathrm{O}, \mathrm{Rb}, \mathrm{Ba}, \mathrm{Th}, \mathrm{Zr}, \mathrm{S},{ }^{87} \mathrm{Sr} /{ }^{86} \mathrm{Sr},{ }^{207} \mathrm{~Pb} /{ }^{204} \mathrm{~Pb}, \delta^{18} \mathrm{O}$, $\mathrm{S} / \mathrm{Se}$, and ${ }^{187} \mathrm{Os} /{ }^{188} \mathrm{Os}$, and a decrease of $\mathrm{P}_{2} \mathrm{O}_{5}, \mathrm{TiO}_{2}, \mathrm{Ti} / \mathrm{Yb}, \mathrm{Ce} / \mathrm{Pb}$, and ${ }^{143} \mathrm{Nd} /{ }^{144} \mathrm{Nd}$ in magma [55]. The sulfur solubility in magma decreases rapidly with an increase of, for example, $\mathrm{SiO}_{2}, \mathrm{CaO}$, and $\mathrm{K}_{2} \mathrm{O}$ contents, which plays a significant role in the sulfur saturation.

The mantle and crust have quite different values of $\delta^{34} \mathrm{~S}, \delta^{18} \mathrm{O}, \mathrm{S} / \mathrm{Se},{ }^{207} \mathrm{~Pb} /{ }^{204} \mathrm{~Pb},{ }^{208} \mathrm{~Pb} /{ }^{204} \mathrm{~Pb}$, ${ }^{187} \mathrm{Os} /{ }^{188} \mathrm{Os}, \gamma_{\mathrm{Os}},\left({ }^{87} \mathrm{Sr} /{ }^{86} \mathrm{Sr}\right){ }_{\mathrm{i}}$, and $\varepsilon_{\mathrm{Nd}}(\mathrm{t})$, and therefore, they can be effectively used to judge the crustal assimilation and contamination of magma [56,57]. It is generally believed that the metallogenic materials (e.g., $\mathrm{S}, \mathrm{Pb}, \mathrm{Cu}, \mathrm{Ni}, \mathrm{Co}, \mathrm{O}$, and $\mathrm{Se}$ ) of magmatic $\mathrm{Ni}-\mathrm{Cu}$ sulfide deposits are mostly from the mantle, but they change significantly with great variation if contaminated with crustal compositions. Firstly, the S/Se value of the mantle is about 2850 4350, whereas that of the crust is about 3500 10,000, with a varied $\delta^{34} S$ value of $<-40 \sim>30 \%$ [58]. Yamamoto (1976) [59] suggested that the increase of the $\mathrm{S} / \mathrm{Se}$ value was the result of the assimilation of crustal sulfur, while the decrease was likely related to the desulfurization of hydrothermal fluids. The S/Se value of the Niubiziliang mafic-ultramafic rocks is 1864 5890 (Table 5), among which three samples are notably higher than that of the mantle and fall into the $S$ additional area (Figure 11). Secondly, the $\delta^{34} S$ value of the mantle is generally within $\pm 2 \%$, while $\delta^{34} S$ values with a wide range of variation are generally considered to be associated with metamorphism and deposition [21]. The sulfide $\delta^{34} S$ value in Niubiziliang is $-8.4 \sim 9.47 \%$, with a significantly wide range of variation (Table 2 ), which indicates a mixture of sulfur with different origins. It is reasonable to attribute the $\delta^{34} \mathrm{~S}$ values of $-1.8 \sim 1.4 \%$ o to a mantle origin, but not the $\delta^{34} \mathrm{~S}$ values of $-8.4 \sim-2.8 \%$ o and 3.7 9.47\% . They are significantly different to that of the upper mantle and are considered to be the result of the sulfur having assimilated from the Paleoproterozoic Jinshuikou Group in NQOB. Thirdly, the sulfides in Niubiziliang have a great variability in terms of the Pb isotopic compositions (Table 3), and their values of ${ }^{207} \mathrm{~Pb} /{ }^{204} \mathrm{~Pb}$ and ${ }^{208} \mathrm{~Pb} /{ }^{204} \mathrm{~Pb}$ are $15.549 \sim 16.161$ and 38.265 42.379, respectively, both of which are higher than that of the mantle (Table 3). Their discriminant diagrams of ${ }^{206} \mathrm{~Pb} /{ }^{204} \mathrm{~Pb} \mathrm{vs}$. ${ }^{207} \mathrm{~Pb} /{ }^{204} \mathrm{~Pb},{ }^{206} \mathrm{~Pb} /{ }^{204} \mathrm{~Pb}$ vs. ${ }^{208} \mathrm{~Pb} /{ }^{204} \mathrm{~Pb}$, and $\Delta \beta$ vs. $\Delta \alpha$ show that they were mainly derived from the orogenic belt, with some upper crust $\mathrm{Pb}$ (Figure 10), which also provides strong support for crustal contamination. Last but not least, the whole-rock $\delta^{18} \mathrm{O}$ value of mantle-derived magma is usually modest, at $6.0 \%$, even with the influence of mantle heterogeneity or magmatic crystallization. It is generally believed that there are two mechanisms for increasing the value of $\delta^{18} \mathrm{O}$ in mantle-derived magmatic hydrothermal alteration and crustal contamination. The $\delta^{18} \mathrm{O}$ value of mafic-ultramafic rocks in Niubiziliang is 6.5 8.1\%o (except for one sample of 5.1\%o), with a wide range of variation (Table 4), all of which are higher than that of the mantle. Therefore, it is more likely that the high $\delta^{18} \mathrm{O}$ values of mafic-ultramafic rocks are the result of contamination with the Jinshuikou Group metamorphic rocks, considering that there is no notable hydrothermal alteration in Niubiziliang. In conclusion, they all give strong evidence of crustal assimilation and contamination resulting in greatly elevated $\mathrm{S} / \mathrm{Se}, \delta^{34} \mathrm{~S}$, ${ }^{207} \mathrm{~Pb} /{ }^{204} \mathrm{~Pb},{ }^{208} \mathrm{~Pb} /{ }^{204} \mathrm{~Pb}$, and $\delta^{18} \mathrm{O}$ values, with a wide range of variation, and play an important role in the sulfur saturation of parental magma in Niubiziliang. Moreover, hornblendes in Niubiziliang have mantle and crust origins, which could indicate crustal contamination, and the ultrabasic magma 
and mantle-origin hornblende evolved to the basic magma and crust-origin hornblende due to the addition of crustal felsic components.

However, according to Ling et al. (2014b) [14], the $\left({ }^{187} \mathrm{Os} /{ }^{188} \mathrm{Os}\right)_{\mathrm{i}}$ values of six sulfides were $0.2750 \sim 1.0397$, with an average of 0.5448 , which was notably higher than that of the mantle-associated Kambalda Ni deposit $(0.10889 \pm 0.00035$, [60]), and also higher than that of the crustal contamination-associated Jinchuan (0.279 \pm 0.018 [61]) and Huangshandong Ni-Cu deposits $(0.25 \pm 0.04$ [62] $)$. At the same time, the corresponding $\gamma_{O s}$ values of sulfides are 56 338, which also provide evidence of crustal contamination, because the more crustal contamination there is, the greater the positive $\gamma_{\mathrm{Os}}$ value [62]. In addition, the Niubiziliang complex has higher $\left({ }^{87} \mathrm{Sr} /{ }^{86} \mathrm{Sr}\right)_{\mathrm{i}}$ values (0.704575 0.705090 [13]) than that of DMM (depleted MORB mantle) and MORB, and they fall into the area between DMM and EMII, which also indicates crustal contamination $[3,6,11]$.

\subsection{Sulfur Saturation Mechanism}

Many investigations have indicated that sulfide liquation led to a sharp loss of Ni content in magma under sulfur saturation, and thus the olivine also showed a loss of $\mathrm{Ni}$ [3,9]. In other words, the Ni content of olivine was significantly controlled by sulfide liquation, and the Ni deficit in olivine was determined by the volume ratio of olivine to sulfide, in magma. Therefore, a sharp decrease of the $\mathrm{Ni}$ content in olivine was considered to be a symbol of deep sulfide liquation, and the greater the $\mathrm{Ni}$ deficit, the more complete the sulfide liquation and the more favorable the conditions for mineralization. The Ni content of olivine in Niubiziliang mafic-ultramafic rocks was $0.08 \sim 0.18 \%$, which was lower than the normal content of olivine by $0.25 \%$, indicating that, in the magma, sulfide liquation had occurred before olivine crystallization, leading to a loss of Ni content in olivine. Stanley and Karleen (1978) [63] believed that the Ni of olivine crystallized in S unsaturated magma was positively correlated with $\mathrm{MgO}$; on the contrary, it represented that the $\mathrm{S}$ of magma had reached saturation. However, the projection points of olivine exhibit a great dispersion and no linear relationship in the Ni-MgO diagram (Figure 15a). At the same time, all of the samples fall in the region of sulfide liquation in the Fo-NiO diagram (Figure 15b) and both indicate that sulfide liquation occurred in the magma when the olivine crystallized, leading to the $\mathrm{NiO}$ deficit in the olivine.
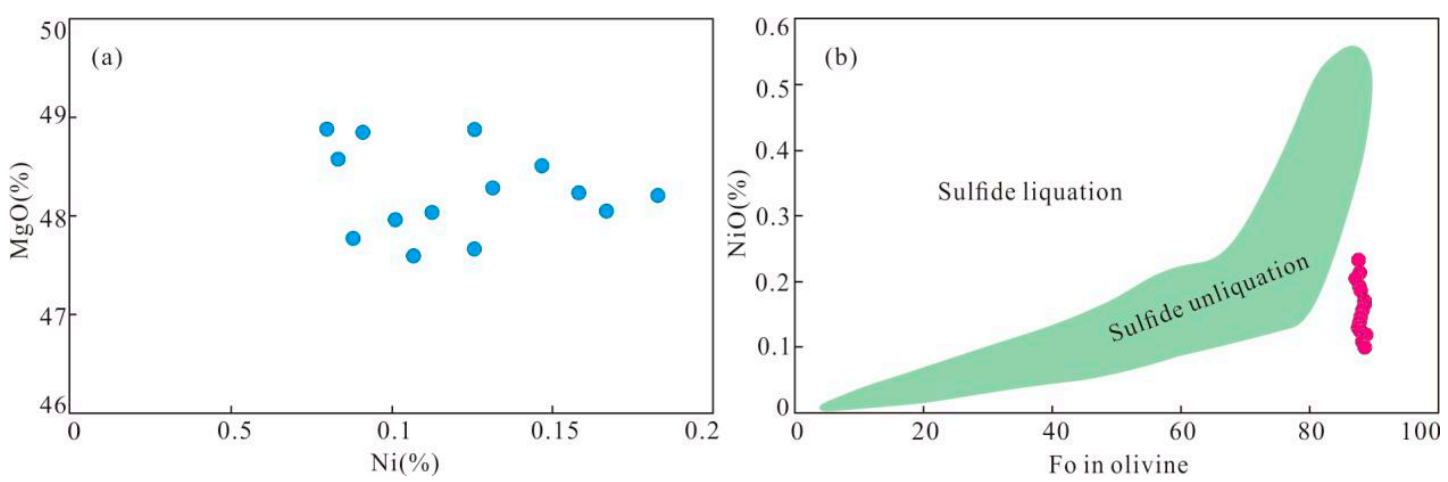

Figure 15. Diagrams of olivine. (a) $\mathrm{Ni}-\mathrm{MgO}$ showing the discrete relationship between $\mathrm{Ni}$ and $\mathrm{MgO}$; (b) Fo-NiO showing the sulfide liquation.

The factors affecting the sulfur solubility in magma mainly include the temperature, pressure, oxygen fugacity, sulfur fugacity, and $\mathrm{FeO}$ content $[2,64]$, among which the solubility of sulfur in magma is negatively correlated with the pressure, but positively correlated with the temperature $[8,65,66]$. However, the temperature has little influence on the sulfur solubility compared with the pressure; that is, even if the sulfur in the mantle source is saturated, it remains unsaturated after invading the crust [3]. Therefore, the sulfur in magma tends to be unsaturated, with a decrease of pressure during the rising process of magma, and sulfur in magma has difficulty reaching saturation and forming an $\mathrm{Ni}-\mathrm{Cu}$ deposit if there is no interference from external factors. A key factor in the formation of magmatic 
sulfide deposits is the saturation of sulfur in magma, causing immiscibility between the silicate magma and sulfides, and enrichment in chalcophile elements in the sulfide melt [3]. Sulfur saturation in magma can generally be achieved by any combination of the following processes: (a) Rapid cooling, such as the sulfides at the bottom of the Bushveld complex [67]; (b) magma mixing, such as the Merensky Reef in Bushveld [68]; (c) fractional crystallization, such as the sulfides in chromitites in Bushveld, and the Hongqiling, Huangshan, and Kalatongke deposits [6]; (d) the addition of external sulfur, such as the Voisey's Bay, Duluth, Tianyu, and Baishiquan deposits [7]; and (e) the addition of crustal compositions, such as the Noril'sk, Huangshannan, and Kalatongke deposits [9]. It should be pointed out that the addition of external sulfur and crustal compositions are attributed to the crustal assimilation and contamination, which play a key role in $\mathrm{Ni}-\mathrm{Cu}$ sulfide deposit formation and often occur during the formation of large-super large Ni-Cu deposits (Voisey's Bay [4], Jinchuan [5], Noril'sk [9], and Xiarihamu [54]).

There could be one or several sulfur saturation mechanisms for the Niubiziliang Ni-Cu deposit. First of all, the low $\mathrm{CaO}$ content of olivine $(<0.01 \%)$ and sufficient differentiation of lithofacies suggest that the magma is crystallizing at a slow rate and higher pressures. In other words, the rate of magma temperature decline is low, which suggests that the rapid cooling of the magma has a limited role in S saturation. Secondly, there is no magmatic inclusion of other constituents found in the Niubiziliang mafic-ultramafic complex, which implies a low probability of magma mixing for S saturation. Thirdly, as previously mentioned, the complete lithofacies of complex and discrimination diagrams suggest the intense fractional crystallization of magma. They lead to the crystallization of large amounts of mafites (e.g., ilmenite, magnetite, olivine, and pyroxene), which alters the magma composition, in particular, rapidly bringing down the $\mathrm{FeO}$ content, resulting in a decrease in the sulfur solubility. Therefore, fractional crystallization is considered to be one of the factors in S saturation in the Niubiziliang Ni-Cu deposit. Last but not least, the crustal assimilation and contamination in Niubiziliang determine the S saturation in at least three ways, as follows: (a) Absorbing the sulfur in Jinshuikou Group and increasing the $S$ concentration in magma supported by the S/Se and $\delta^{34} S$ values; (b) altering the composition of magma and decreasing the solubility of sulfur in magma, such as the increase of $\mathrm{SiO}_{2}$, $\mathrm{K}_{2} \mathrm{O}, \mathrm{Al}_{2} \mathrm{O}_{3}$, and $\mathrm{CaO}$ content; and (c) enhancing the $f_{\mathrm{O} 2}$ of magma, resulting in a decrease of the sulfur solubility supported by the $\delta^{18} \mathrm{O}$ values. Therefore, we conclude that the fractional crystallization of magma and crustal assimilation and contamination are the main mechanisms of sulfur saturation in the parental magma of the Niubiziliang Ni-Cu deposit. However, the effect of crustal assimilation and contamination on sulfur saturation is much greater than that of fractional crystallization.

As the primary magma evolved, the fractional crystallization of olivine and pyroxene, together with crustal assimilation and contamination, caused sulfur saturation and strong sulfide immiscibility. Therefore, the parental magma differentiated into a series of magma with various sulfide melting in the magma chamber at a depth of $35.45 \sim 36.55 \mathrm{~km}$, including barren, ore-bearing, ore-rich, and ore magma. Then, these magmas were emplaced in multiple stages under the geo-background of continuous extension during the middle-late Devonian in NQOB, and the Niubiziliang mafic-ultramafic complex with $\mathrm{Ni}-\mathrm{Cu}$ mineralization finally formed in the existing space at a depth of $8.13 \sim 8.70 \mathrm{~km}$.

\section{Conclusions}

(1) The parental magma of the Niubiziliang complex is considered to be high-Mg picritic basalt, with $\mathrm{MgO}$ and $\mathrm{NiO}$ contents of $14.95 \sim 16.58 \%$ and $0.053 \sim 0.068 \%$, respectively, indicating a high degree of partial melting of the depleted mantle.

(2) The Niubiziliang complex formed at a moderate depth $(8.13 \sim 8.70 \mathrm{~km})$ with the temperature and pressure of $1159 \sim 1253{ }^{\circ} \mathrm{C}$ and $2.15 \sim 2.30 \mathrm{kbar}$, respectively, and the crystallization sequence of the main silicate minerals is olivine $\rightarrow$ pyroxene-(plagioclase) $\rightarrow$ hornblende, which is consistent with the observation made under the microscope. However, the olivines and some pyroxenes likely crystallized in the magma chamber at a depth of $35.45 \sim 36.55 \mathrm{~km}$, with a high temperature $\left(1289 \sim 1369{ }^{\circ} \mathrm{C}\right)$ and pressure (9.38 9.67 kbar). 
(3) The primary magma of Niubiziliang underwent significant fractional crystallization and crustal assimilation and contamination, which resulted in sulfur saturation and sulfide immiscibility in the magma. However, the contribution of crustal assimilation and contamination to sulfur saturation is much greater than that of fractional crystallization.

Supplementary Materials: The following are available online at http://www.mdpi.com/2075-163X/10/10/837/s1, Table S1: The spectral lines, standards and count times that were used and average of detection limits of electron microprobe analysis, Table S2: Electron microprobe analyses (wt\%) of olivine from the Niubiziliang mafic-ultramafic complex, Table S3: Electron microprobe analyses (wt $\%$ ) of pyroxene from the Niubiziliang mafic-ultramafic complex, Table S4: Electron microprobe analyses ( $\mathrm{w} t \%)$ of plagioclase from the Niubiziliang mafic-ultramafic complex, Table S5: Electron microprobe analyses (wt\%) of hornblende from the Niubiziliang mafic-ultramafic complex.

Author Contributions: Conceptualization, L.L., F.S. and S.T.; Investigation, L.L., F.S., H.L., L.Y., F.W., X.W., D.S. and Y.W.; Writing—original draft preparation, L.L.; Writing-review and editing, L.L., F.S. and S.T. All authors have read and agreed to the published version of the manuscript.

Funding: This research was financially supported by the Initial Scientific Research Fund of Postdoctoral Fellow at Yunnan University (C176220200), and the Geological Exploration Fund Project of Qinghai Province (2014057017ky017).

Acknowledgments: We would like to thank the Laboratories of the Chinese Academy of Geological Sciences, Beijing Research Institute of Uranium Geology, for their advice and assistance during the electron microprobe; $\mathrm{S}-\mathrm{Pb}-\mathrm{O}$ isotopic; and S, Se and Te concentration analysis. We also thank the Nuclear Industry Bureau of Qinghai Province for their assistance during the field investigation.

Conflicts of Interest: The authors declare no conflict of interest.

\section{References}

1. Lv, L.S.; Liu, J.; Zhang, Z.H.; Xie, G.Q. Temporal-spatial distribution and geodynamic setting of magmatic Ni-Cu-(PGE) sulfide deposits in China. Acta Petrol. Sin. 2007, 23, 2561-2594. (In Chinese)

2. Lightfoot, P.C.; Hawkesworth, C.J.; Hergt, J.; Naldrett, A.J.; Gorbechev, N.S.; Fedorenko, V.A.; Doherty, W. Remobilisation of the continental lithosphere by a mantle plume: Major-, trace-element, and $\mathrm{Sr}-, \mathrm{Nd}-$, and $\mathrm{Pb}-$ isotope evidence from picritic and tholeiitic lavas of the Noril'sk District, Siberian Trap, Russia. Contrib. Mineral. Petrol. 1993, 114, 171-188. [CrossRef]

3. Naldrett, A.J. World-class Ni-Cu-PGE deposits: Key factors in their genesis. Miner. Depos. 1999, 34, $227-240$. [CrossRef]

4. Li, C.S.; Naldrett, A.J. Melting reactions of gneissic inclusions with enclosing magma at Voisey's Bay, Labrador, Canada: Implications with respect to ore genesis. Econ. Geol. 2000, 95, 801-814. [CrossRef]

5. Lehmann, J.; Arndt, N.; Windley, B.; Zhou, M.F.; Wang, C.Y.; Harris, C. Field relationships and geochemical constraints on the emplacement of the Jinchuan intrusion and its Ni-Cu-PGE sulfide deposit, Gansu, China. Econ. Geol. 2007, 102, 75-94. [CrossRef]

6. Wu, F.Y.; Wilde, S.A.; Zhang, G.L.; Sun, D.Y. Geochronology and petrogenesis of the post-orogenic Cu-Ni sulfide-bearing mafic-ultramafic complexes in Jilin Province, NE China. J. Asian Earth Sci. 2004, 23, 781-797. [CrossRef]

7. Tang, Z.L.; Xu, G.; Wang, Y.L.; Qiu, G.L.; Dai, J.F. The new exploration of magmatic mineralization: Small intrusion mineralization and geological prospecting breakthrough. Northwest. Geol. 2012, 45, 1-16. (In Chinese)

8. Li, C.S.; Ripley, E.M. The giant Jinchuan Ni-Cu-(PGE) deposit: Tectonic setting, magma evolution, ore genesis and exploration implications. Rev. Econ. Geol. 2011, 17, 163-180.

9. Iacono-Marziano, G.; Ferraina, C.; Gaillard, F.; Di Carlo, I.; Arndt, N. Assimilation of sulfur and carbonaceous rocks: Experimental study, thermodynamic and application to the Noril'sk-Talnakh region (Russia). Ore Geol. Rev. 2017, 90, 399-413. [CrossRef]

10. Li, C.S.; Naldrett, A.J. Sulfide capacity of magma: A quantitative model and its application to the formation of sulfide ores at Sudbury. Econ. Geol. 1993, 88, 1253-1260. [CrossRef]

11. Zhao, S.X.; Wang, Y.G.; Li, C.L.; Zhuang, Y.; Geng, A.Q.; Wang, X.P. The copper-nickle mine features of Niubiziliang in north-west margin of Chaidamu Basin, and discoverable significance. Northwest. Geol. 2012, 45, 202-210. (In Chinese) 
12. Zhao, Y.F.; Kang, Z.; Ling, J.L.; Zhao, S.X.; Wang, Y.G.; Shen, D.L.; Jiang, C.Y. Geological feature and genesis of Niubiziliang Cu-Ni sulphide deposit in the northern margin of Qaidam Block. J. Earth Sci. Environ. 2012, 34, 12-21. (In Chinese)

13. Ling, J.L.; Zhao, Y.F.; Kang, Z.; Jiang, C.Y.; Song, Z.B.; Zhao, S.X.; Wang, Y.G. Petrogenesis and mineralization of Niubiziliang mafic-ultramafic intrusion in the northern margin of Qaidam Block, NW China. Acta Petrol. Sin. 2014, 30, 1628-1646. (In Chinese)

14. Ling, J.L.; Song, Y.F.; Jiang, C.Y.; Song, Z.B.; Zhao, Y.F. Platinum-group elements and Re-Os isotopic characters of the Niubiziliang Ni-Cu deposit in the northern margin of the Qaidam Block, Northwest China. Geol. Explor. 2014, 50, 138-144. (In Chinese)

15. Qian, B.; Zhang, Z.W.; Zhang, Z.B.; Shao, J. Zircon U-Pb geochronology of Niubiziliang mafic-ultramafic intrusion on the northwest margin of Qaidam Basin, Qinghai. Geol. China 2015, 42, 482-493. (In Chinese)

16. Yu, L.; Sun, F.Y.; Li, L.; Li, B.L.; Peng, B.; Xu, C.H.; Li, R.H.; Wang, F.; Shen, D.L. Geochronology, geochemistry, and Sr-Nd-Hf isotopic compositions of mafic-ultramafic intrusions in the Niubiziliang Ni-(Cu) sulfide deposit, North Qaidam Orogenic Belt, NW China: Implications for magmatic source, geodynamic setting, and petrogenesis. Lithos 2019, 326-327, 158-173. [CrossRef]

17. Ni, J.L.; Wang, J.C.; Lv, B.F.; Lin, Y.X.; Xia, B. Structural features of the Altun Mountain and its fault systems during Mesozoic and Cenozoic. J. Guilin Univ. Technol. 2008, 28, 295-300. (In Chinese)

18. Wang, F.; Wang, L.; Sun, F.Y.; Li, L.; Liu, J.L.; Tian, X.C. Zircon U-Pb geochronology and geochemistry of Niubiziliang granodiorite in northern margin of Qaidam Basin. Glob. Geol. 2017, 36, 93-104. (In Chinese)

19. Li, R.H.; Sun, F.Y.; Li, L.; Bai, Y.N.; Wang, F.; Jiang, H.F.; Yu, L. U-Pb dating, geochemistry, and Hf isotopic compositions of diorite from the Niubiziliang Ni-(Cu) deposit in Qinghai Province. Acta Geol. Sin. 2017, 91, 2273-2284. (In Chinese)

20. Sun, F.Y.; Li, L.; Li, B.L.; Chen, G.J.; Li, R.H.; Yu, L.; Qian, Y.; Wang, L.; Huo, L.; Wang, L.L.; et al. Research Report of Ore-Controlling Conditions and Prospecting Breakthrough of the Magmatic Cu-Ni Sulfide Deposits in Niubiziliang Area, Qinghai Province; Jilin University: Changchun, China, 2019. (In Chinese)

21. Jiang, H.F.; Sun, F.Y.; Li, L.; Li, R.H.; Yu, L.; Wang, F.; Shen, D.L. Geochronology, geochemistry and Hf isotope of monzogranite in Niubiziliang of Qinghai. Glob. Geol. 2016, 19, 153-163.

22. Ling, J.L. Petrogenesis of Mafic-Ultramafic Intrusions and Minerogenesis of Nickel Sulfide Deposit in the Periphery of Qaidam Block, Qinghai China. Ph.D. Thesis, Chang'an University, Xi'an, China, 2014. (In Chinese).

23. Dick, H.J.B.; Bullen, T. Chromian spinel as a petrogenetic indicator in abyssal and alpine-type peridotites and spatially associated lavas. Contrib. Mineral. Petrol. 1984, 86, 54-76. [CrossRef]

24. Wang, G. Metallogenesis of Nickel Deposits in Eastern Kunlun Orogen, Qinghai Province. Ph.D. Thesis, Jilin University, Changchun, China, 2014. (In Chinese).

25. Lv, L.S.; Mao, J.W.; Zhou, Z.H.; Li, H.B.; Zhang, Z.H.; Wang, Y.F. Mineral chemistry of ore-bearing ultramafic rocks from the Hongqiling No. 1 and 7 intrusions in Jilin University: Constraints on the magmatic processes and the metallogenesis of Ni-Cu sulfide deposits. Acta Petrol. Sin. 2012, 28, 319-344. (In Chinese)

26. Chen, L.M.; Song, X.Y.; Danyushevsky, L.V.; Xiao, J.F.; Li, S.B.; Guan, J.X. Correlation between Ni and $\mathrm{MgO}$ contents of olivine in Segment I of the Jinchuan intrusion, NW China, and its geological implication. Acta Petrol. Sin. 2009, 25, 3369-3378. (In Chinese)

27. Morimoto, N. Nomenclature of pyroxenes. Mineral. Mag. 1988, 52, 535-550. [CrossRef]

28. Qiu, J.X.; Liao, Q.A. Petrogenesis and Cpx mineral chemistry of Cenozoic basalts from Zhejiang and Fujian of Eastern China. Volcanol. Miner. Resour. 1996, 17, 16-25. (In Chinese)

29. Parsons, I. Feldspars defined and described: A pair of posters published by the Mineralogical Society. Sources and Supporting Information. Mineral. Mag. 2010, 74, 529-551. [CrossRef]

30. Leake, B.E.; Woolley, A.R.; Arps, C.E.S.; Birch, W.D.; Gilbert, M.C.; Grice, J.D.; Hawthorne, F.C.; Kato, A.; Kisch, H.J.; Krivovichev, V.G.; et al. Nomenclature of amphiboles: Report of the subcommittee on amphiboles of the international mineralogical association commission on new minerals and mineral names. Int. Conf. Form. Concept Anal. 1997, 4390, 181-196.

31. Jiang, C.Y.; An, S.Y. On chemical characteristics of calcic amphiboles from igneous rocks and their petrogenesis significance. Miner. Petrol. 1984, 3, 1-9. (In Chinese)

32. Ripley, E.M.; Li, C.S. Applications of stable and radiogenic isotopes to magmatic Cu-Ni-PGE deposits: Examples and cautions. Earth Sci. Front. 2007, 14, 124-131. [CrossRef] 
33. Zartman, R.E.; Doe, B.R. Plumbo tectonics-the model. Tectonophysics 1981, 75, 135-162. [CrossRef]

34. Smith, J.W.; Holwell, D.A.; McDonald, I.; Boyce, A. The application of S isotopes and S/Se ratios in determining ore-forming processes of magmatic Ni-Cu-PGE sulfide deposits: A cautionary case study from the northern Bushveld Complex. Ore Geol. Rev. 2016, 73, 148-174. [CrossRef]

35. Roeder, P.L.; Emslie, R.F. Olivine-liquid equilibrium. Contrib. Mineral. Petrol. 1970, 29, 275-289. [CrossRef]

36. Ross, J.R.; Travis, G.A. The nickel sulfide deposits of Western Australia in global perspective. Econ. Geol. 1981, 76, 1291-1329. [CrossRef]

37. Zhang, Z.C.; Wang, F.S. A method for identifying primary magma-Examples from picrite and alkali basalts. J. Jilin Univ. (Earth Sci. Ed.) 2003, 33, 130-134. (In Chinese)

38. Chen, L.M.; Song, X.Y.; Danyushevsky, L.V.; Xiao, J.F.; Zhu, D.; Zhou, G.F.; Guan, J.X.; Liu, S.R.; Zheng, W.Q. Parental magma composition of the Jinchuan intrusion, Gansu Province and MELTS thermodynamic modelling of fractional crystallization. Acta Geol. Sin. 2009, 83, 1302-1315. (In Chinese)

39. Li, C.S.; Zhang, Z.W.; Li, W.Y.; Ripley, E.M. Geochronology, petrology and Hf-S isotopes of the newly-discovered, world-class Xiarihamu magmatic Ni-Cu deposit in the Qinghai-Tibet Plateau, western China. Lithos 2015, 216-217, 224-240. [CrossRef]

40. Tao, Y.; Gao, Z.M.; Luo, T.Y.; Qi, J.D.; He, Y.J.; Yang, T.X. Inversion of primary magma composition for Jinbaoshan ultramafic intrusion, Yunnan. Acta Petrol. Sin. 2002, 18, 70-82. (In Chinese)

41. Sato, H. Nickel content of basaltic magmas: Identification of primary magmas and a measure of the degree of olivine fractionation. Lithos 1977, 10, 113-120. [CrossRef]

42. Qiu, J.X. Magmatic Petrology; Geological Publishing House: Beijing, China, 1986; pp. 140-156. (In Chinese)

43. Simkin, T.; Smith, J.V. Minor element distribution in olivine. J. Geol. 1970, 78, 304-325. [CrossRef]

44. Putirka, K.D. Thermometers and barometers for volcanic systems. Rev. Mineral. Geochem. 2008, 69, 61-120. [CrossRef]

45. Mercier, J.C.; Benoit, V.; Girardeau, J. Equilibrium state of diopside-bearing harzburgites from ophiolites: Geobarometric and geodynamic implications. Contrib. Mineral. Petrol. 1984, 85, 391-403. [CrossRef]

46. Papike, J.J.; Cameron, K.L.; Baldwin, K. Amphiboles and pyroxenes: Characterization of other than quadrilateral components and estimates of ferric iron from microprobe data. Geol. Soc. Am. Abstr. Programs 1974, 6, 1053-1054.

47. Bagiński, B.; Dzierzanowski, P.; Macdonald, R.; Upton, B.G.J. Complex relationships among coexisting pyroxenes: The Palaeogene Eskdalemuir dyke, Scotland. Mineral. Mag. 2009, 73, 929-942. [CrossRef]

48. Ridolfi, F.; Renzulli, A.; Puerini, M. Stability and chemical equilibrium of amphibole in calc-alkaline magmas: An overview, new thermobarometric formulations and application to subduction-related volcanoes. Contrib. Mineral. Petrol. 2009, 160, 45-66. [CrossRef]

49. Frey, F.A.; Green, D.H.; Roy, S.D. Integrated models of basalt petrogenesis: A study of quartz tholeiites to olivine melilities from south eastern Australia utilizing geochemical and experimental petrological data. J. Petrol. 1978, 19, 463-513. [CrossRef]

50. Green, D.H. Genesis of archean Peridotitic magmas and constraints on archean geothermal gradients and teetonies. Geology 1975, 3, 15-18. [CrossRef]

51. Späth, A.; Le Roex, A.P.; Opiyo-Akech, N. Plume-lithosphere interaction and the origin of continental rift-related alkaline volcanism-the Chyulu Hills Volcanic Province, Southern Kenya. J. Petrol. 2001, 42, 765-787. [CrossRef]

52. Ni, Z.Y. Several recently proposed geothermometers. Geol. Sci. Technol. Inf. 1991, 10, 7-12. (In Chinese)

53. Depaolo, D.J. Trace element and isotopic effects of combined wallrock assimilation and fractional crystallization. Earth Planet. Sci. Lett. 1981, 53, 189-202. [CrossRef]

54. Peng, B.; Sun, F.Y.; Li, B.L.; Wang, G.; Li, S.J.; Zhao, T.F.; Li, L.; Zhi, Y.B. Thegeochemistry and geochronology of the Xiarihamu II mafic-ultramafic complex, Eastern Kunlun, Qinghai Province, China: Implications for the genesis of magmatic Ni-Cu sulfide deposits. Ore Geol. Rev. 2016, 73, 13-28. [CrossRef]

55. Mir, A.R.; Alvi, S.H.; Balaram, V. Geochemistry of the mafic dykes in parts of the Singhbhum granitoid complex: Petrogenesis and tectonic setting. Arab. J. Geosci. 2011, 4, 933-943. [CrossRef]

56. Peck, D.C.; Keays, R.R. Insights into the behaviour of precious metals in primitive, S-undersaturated magmas: Evidence from the Heazlewood River Complex, Tasmania. Can. Mineral. 1990, 28, 553-577.

57. Queffurus, M.; Barnes, S.J. A review of sulfur to selenium ratios in magmatic nickel-copper and platinum-group element deposits. Ore Geol. Rev. 2015, 69, 301-324. [CrossRef] 
58. Eckstrand, O.R.; Cogolu, E. Se/S Evidence Relating to Genesis of Sulphides in the Crystal Lake Gabbro, Thunder Bay, Ontario; Geological Association of Canada-Abstract Programs; Geological Association of Canada: St. John's, NL, Canada, 1986; Volume 11, pp. 1-66.

59. Yamamoto, M. Relationship between Se/S and sulfur isotope ratios of hydrothermal sulfide minerals. Miner. Depos. 1976, 11, 197-209. [CrossRef]

60. Foster, J.G.; Lambert, D.D.; Frick, L.R. Re-Os isotopic evidence for genesis of Archaean nickel ores from uncontaminated komatiites. Nature 1996, 382, 703-706. [CrossRef]

61. Yang, G.; Du, A.D.; Lu, J.R.; Qu, W.J.; Chen, J.F. Re-Os (ICP-MS) dating of the mass ores in Jinchuan Cu-Ni-Pt deposit. Sci. China (Ser. D) 2005, 35, 241-245. (In Chinese)

62. Mao, J.W.; Yang, J.M.; Qu, W.J.; Du, A.D.; Wang, Z.L.; Han, C.M. Re-Os dating of Cu-Ni sulfide ores from Huangshandong deposit in Xinjiang and Its geodynamic significance. Miner. Depos. 2002, 21, 323-330.

63. Stanley, R.H.; Karleen, E.D. Nickel partitioning between olivine and silicate melt. Earth Planet. Sci. Lett. 1978, 40, 203-219.

64. Shima, H.; Naldrett, A.J. Solubility of sulfur in an ultramafic melt and the relevance of the system Fe-S-O. Econ. Geol. 1975, 70, 960-967. [CrossRef]

65. Wendlandt, R.F. Sulfide saturation of basalt and andesite melts at high pressures and temperatures. Am. Mineral. 1982, 67, 877-885.

66. Mavrogenes, J.A.; O'Neill, H.S.C. The relative effects of pressure, temperature and oxygen fugacity on the solubility of sulfide in mafic magmas. Geochim. Cosmochim. Acta 1999, 63, 1173-1180. [CrossRef]

67. Maier, W.D.; Barnes, S.J.; Waal, S.A.D. Exploration for magmatic Ni-Cu-PGE sulphide deposits: A review of recent advances in the use of geochemical tools, and their application to some South African ores. S. Afr. J. Geol. 1998, 101, 237-253.

68. Lambertt, D.D.; Walker, R.J.; Morgan, J.W. Re-Os and Sm-Nd isotope geochemistry of the Stillwater Complex, montana: Implications for the prteogenesis of the J-M Reef. J. Petrol. 1998, 35, 1717-1753. [CrossRef]

(C) 2020 by the authors. Licensee MDPI, Basel, Switzerland. This article is an open access article distributed under the terms and conditions of the Creative Commons Attribution (CC BY) license (http://creativecommons.org/licenses/by/4.0/). 